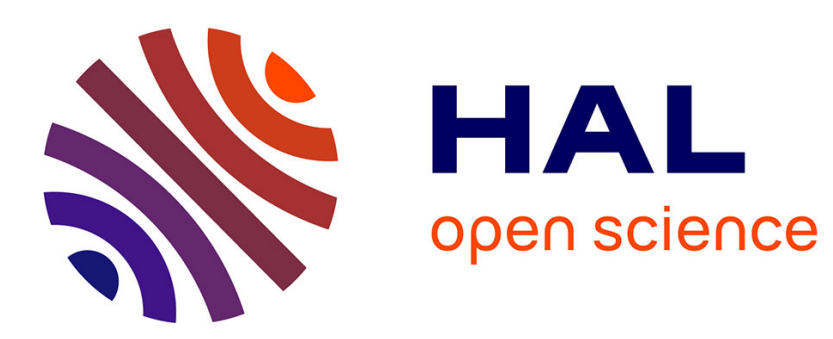

\title{
How do judges judge? Evidence of local effect on French bankruptcy judgments \\ Stéphane Esquerré
}

\section{To cite this version:}

Stéphane Esquerré. How do judges judge? Evidence of local effect on French bankruptcy judgments. 2019. hal-02291688

\section{HAL Id: hal-02291688 \\ https://hal.science/hal-02291688}

Preprint submitted on 19 Sep 2019

HAL is a multi-disciplinary open access archive for the deposit and dissemination of scientific research documents, whether they are published or not. The documents may come from teaching and research institutions in France or abroad, or from public or private research centers.
L'archive ouverte pluridisciplinaire HAL, est destinée au dépôt et à la diffusion de documents scientifiques de niveau recherche, publiés ou non, émanant des établissements d'enseignement et de recherche français ou étrangers, des laboratoires publics ou privés. 


\title{
How do judges judge? Evidence of local effect on French bankruptcy judgments
}

\author{
Stéphane Esquerré
}

September 19, 2019

\begin{abstract}
Law and Economics literature recently gazed upon the "failure of judges" showing the various biases, psychological but also political, they can display. One of the seminal criticisms against bankruptcy judges focused on their attempt to go beyond the strict applications of law in their decisions. The main drawback is their lack of businessrelated expertise. The French bankruptcy system was created four centuries ago with this last problem in mind and remains unique today. The bankruptcy judges are elected among local businessmen and top executives. They rule without any professional judge along them, like in mixed courts in Belgium. They are given a key role in the decision as in the U.S.. This chapter shows how judges display a home bias when the area suffers from economic turmoil. They attempt to favor the reorganization of bankrupt firms when the local unemployment rate is high. The analysis is based on an original dataset of all filings for restructuring (Redressement Judiciaire) from 2006 to 2013. This is shown to hold robust despite several tests using survival analysis in a competing risk setting. This effect is found to reduce the time of negotiation between the firm and its creditors with no effect on the survival of the firm after the reorganization plan was agreed upon. We infer that judges cram-down decisions faster in these contexts and let creditors bear the costs of these reorganisations. It underlines how Courts wish to implement decisions that exceed solely debt-collection with a concern for the local area at the risk of hurting the firm's creditors.
\end{abstract}

JEL-Classification: G33, H73, K22

Keywords: Bankruptcy, Judge, Interjurisdictional Differentials and Their Effects

\section{Introduction}

French bankruptcy system is widely quoted as both an example of civil tradition and pro-continuation (or pro-debtor) system in L\&E. But one of its unique feature is rarely studied, its bankruptcy judges. In France, they are 
not professional judges but consular judges. They are local executives and entrepreneurs working voluntarily for the court and elected in each jurisdiction $^{1}$. This system has existed for four centuries and has resisted to major changes for two main reasons (Montebourg and F. 1998) : judges are legitimated by their knowledge and this organization is cost and time efficient. France thus offers a unique system where judges avoid many of the critics which should explain the "failure of judges" (Shleifer 2012) : they are experts, elected for their skills, and for a finite time - a 4-year mandate, renewable thrice, for a maximum of fourteen years. At the same time, they play a key role in the decision making. Similarly to the U.S., the French system is court-administered and judges can cram-down decisions towards the creditors, e.g. if a firm files for restructuring, the judge can force them upon a restructuring plan.

Blazy et al. 2011 showed how the decisions of French bankruptcy judges are in line with the firm's interest like they are supposed to ${ }^{2}-$ but "social considerations prevail in the arbitration". When choosing between alternative buying offers of a bankrupt firm, they "consider financial issues as well the ones preserving the highest number of employees before the offer price". This behavior is expected since French law itself ranks the aims of bankruptcy in a similar way: first the protection of employment, then the pursue of the firm's activity and last the write-off of debts. These results are based on the sole firm's characteristics and the judge does not pursue any other motive here than the firm's interest. The authors also confirm the findings in LoPucki and Doherty 2007 that the proceeding's outcome does not affect global recovery rates. Yet, we reckon here that judges make their decisions having in mind the negative impact they can have on non-investors, the employees but also the commercial partners of the firms including her suppliers and customers. These judgments may thus prioritize social interest, in particular local unemployment rate with less concerns on the other stakeholders the creditors. The judges' decision to liquidate the firm that applied for restructuring first affects the local economy of the jurisdiction. As local entrepreneurs, they are well aware of the economic context at the time of decision. By law, the objective function of the court takes only into account the stakeholders of the firms (employees, investors, creditors). We wonder whether they add to their objective function external factors. This would be explained by them being elected locally and being sensitive to these external factors due to their job.

We test whether courts change their decisions depending on the local economic context, in particular if they prevent firms to shut down in time of economic turmoil. The aim here is to show that the specific nature of

\footnotetext{
${ }^{1}$ Except in three legal districts - Alsace-Moselle - which maintain an échevinage system where the courts are composed by a mix of professional judges and elected professionals like in Belgium or Switzerland

${ }^{2}$ Vallens2006
} 
French judges could help them favour social interest. French bankruptcy judges often claim pragmatism as fairness to be core values which explain how they interpret the law ${ }^{3}$. French courts may choose to depart from a strict application of law. They could take liberty and choose to implement what they define as efficient rulings, which would have the least harmful impact on the local economy.

Seeing bankruptcy as more than a debt-collection process, but a redistributive policy-solution which integrates "non-investors" interest, was deemed particularly prejudicial in the case of the U.S.. Yet this criticism was mainly motivated by the nature of U.S. bankruptcy judges, being civil servants (Frost 1995). Through their knowledge and networks, consular judges may be able to overcome some of these limits. This paper does not wish to question the principles judges should base their decision upon ${ }^{4}$. We are solely interested on how the judges's status may help them apprehend - or think they can - the overall social impact of their decisions. We wish to analyse how these deviations from decisions based on the firm's characteristics affect the firm and its creditors.

Our paper relates to the legal realism literature. We question various biases that affect the rulings, such as the economic environment of the court. There are controversial results on how the economic context may change the resulting judgment. The main concern is for law to be applied in the same way for all citizens and across the entire national territory. Two papers show opposite results. Ichino, Polo, and Rettore 2003 find Courts to be more favorable to workers in higher unemployment context. Marinescu 2011 uses a 1992 survey on U.K. employment tribunals and finds that both unemployment and bankruptcy rates significantly decrease the chances for a judgment to be in favor of dismissed employees thus being more sensitive to the firms' interest.

The above strand of the literature assumes that judges do not simply apply the law but cover their judgments with a political dimension - expressing their beliefs or even implicit biases ${ }^{5}$. Ben-Ishai and Lubben 2011 in this regard states that the U.S. reorganisation bankruptcy process, Chapter 11, has been an efficient government tool to provide support to the automotive industry. The rulings can also be swayed because of direct political pressure as proven by the study by Lambert-Mogiliansky, Sonin, and Zhuravskaya 2007 on Russian Commercial Courts after the enforcement of the new 1998 bankruptcy law. They demonstrated how the regional governor affected the

\footnotetext{
${ }^{3}$ As documented in Lazega and Mounier 2009; Lazega 2009 based on their interviews of Parisian bankruptcy judges.

${ }^{4}$ On the subject, see Lyon-Caen and Urban 1990. Also Lazega 2009 has reckoned based on direct interviews - that the judges in Commercial Courts apply their decision following principles similar to Posner's legal pragmatism Posner 1993.

${ }^{5}$ See Irwin and Real 2010; Kang et al. 2011 for a review on how they form and can affect decisions
} 
decisions of the courts because of how judges' career are dependent on these regional authorities. Both papers rehabilitate the political dimension of these decisions though it is supposed here that judgments are not swayed by the judges' motives but by the general system.

But the particularity of French consular judges makes them susceptible to peer-pressure. In Lazega 2009, the author has attended interviews with most of the judges in Paris Commercial Court. He shows the judges' punitivity and interventionism in the judicial process vary strongly and can be linked with their past career and specifically in which business area they worked. Such a statement seems reinforced by their being elected through the sponsorship of their employer's association or their business sector's association. It is not necessarily an explicit peer-pressure and it could be explained through industry-specific representations that affect their statements.

We look at all restructuring filings ${ }^{6}$ that happened from 2006 to $2013^{7}$. This gave us access to 65,899 cases over the period, in the jurisdictions with only non-professional judges. We check whether an increase of the local unemployment rate heightens the chances of an agreement on a reorganization plan. The judge has to choose among several options after the filing : enforce a reorganization plan ; convert the restructuring to a liquidation proceeding, generally ending in a piecemeal sale; selling the firm as a going concern. The firm can also end up being liquidated because of lack of assets (insuffisance d'actifs) because of its economic distress during the judicial process. Since the judges can cram down the decision, they can choose which option to enforce.

The effect of local unemployment is tested with a survival analysis model on the different outcomes after filing. An increase in local unemployment rate is found to increase the transition hazard of a reorganization plan. This result holds robust after a battery of tests which confirms that the estimates are not driven by alternative channels. In particular we control for differential effects over time which may be driven by the industry, the size or other specifics of the models we use. Our aim is to pin down the sole local economic effect not affected by these potential other biases.

This increase in the hazard rate of reorganisation plan implies that the observation period $^{8}$ is shorter. Bankruptcy in France, like in the US, starts with automatic stay, an automatic injunction that halts actions by creditors to collect debts. Less time in bankruptcy means that the time during which the creditors remain without payments is reduced. But it also implies that

\footnotetext{
${ }^{6}$ Redressement Judiciaire

${ }^{7}$ This period covers two financial crises, the aftermath of the subprime crisis and the Eurozone debt crisis. This is why we always control our local economic variable to national ones in order to test for these local variations each time

${ }^{8}$ The observation period of a reorganisation is the period after the filing when the firm lists her debts, negotiates with her creditors and may offer a reorganisation plan that the court must agree upon.
} 
the time of negotiation is reduced. Since we control with financial ratios, this result holds irrespective of the financial situation of the firm. Crammingdown decision by court probably becomes more frequent.

There are multiple arguments in favour of this analysis. Our study covers eight years and most secured creditors like bank are national and not local. The assumption that at times of local economic turmoil secured creditors agree to alleviate some of the charges may not seem plausible. What's more, the liquidation bias of creditors is documented (see for example Blazy and Chopard 2012). According to Sharfman 2004, US bankruptcy judges show loss-aversion bias that lead them to taking decisions in favor of debtors. Last, if the reorganisation plan were more demanding for the firm, this could have an effect on the firm's survival. We check whether these deviations affect the survival of a firm after the plan was agreed upon ${ }^{9}$. We define failure as the proceeding being converted into Liquidation or the firm is shut down . We find no such effect, judges do not let any firm being reorganized but are apparently more lax on the conditions regardless of the impact on the firm's creditors. Reorganization plans generally stretch for ten years so this effect may be driven by lack of history in our data.

This result implies that part of the reorganisation costs are increasingly taken by creditors in time of turmoil. This can have externality on the credit-lending process. When facing local economic turmoil, some creditors should me less willing to finance some projects, with the risk of a shortage in credit-lending. Judges may justify to first deal with the firm at the utmost risk in a particularly stressing environment. They may also consider that the creditors at risk are not directly under their supervision - either because they are nationwide or because they depend on other jurisdictions. Another explanation inspired by the work of Iverson 2017 is that the judges are being stressed by the increase in bankruptcy caseloads that is consecutive to the economic turmoil. They may prefer to delay the decision to shut down the firm afterward and choose the "default" solution, i.e. the reorganization plan. To check the possibility of case overload, we include the number of past proceedings over the last 12 months before a firm has filed. This decision by default should imply an increase in liquidation for the firms that were prolonged because of the changes in local environment.

Together, these results confirm that there are deviations in judgment because of a troubled local economic context. These changes impact only the firm's creditors and not its survival. Our findings relate to the controversial results mentioned before and ascertain the impact of the economic environment on decisions, following Ichino, Polo, and Rettore 2003.

Finally our results also relate to the question of "continuation bias" in pro-continuation systems such as the U.S.'s. It was widely criticized because

\footnotetext{
${ }^{9}$ We had chosen to test for survival rather than the usual recidivism rate since the turnover to bankruptcy is less frequent in France than for the U.S. Chapter 11.
} 
it was thought too debtor-friendly which explained the wish of a reform in 2005. Nonetheless Morrison 2007 or Warren and Westbrook 2007 and Warren and Westbrook 2008 proved the high screening ability of American Courts and the short delays it took in deciding. However some papers show that pro-debtor decisions could be driven by behavioural bias such as lossaversion (Sharfman 2004) or even lack of experience (Iverson et al. 2019). This questions the opposition between "Proceduralists" vs. "Traditionalists" (Ferriell and Janger 2013) on the need for judges to help rescuing businesses despite potential cost for creditors. The latter view bankruptcy as "a deliberate distributional policy in favor of all those whom a business failure would have hurt" (Warren 2004).

The rest of the paper proceeds as follows. Section 2 gives more background about the specifics of the judges in French Commercial courts and on the local implementation of these Courts. Section 3 describes our empirical strategy. Section 4 provides information on the data used in the samples. Section 5 analyses the impact of local unemployment on the decisions and its effect on the firms' survival. We conclude in section 6 .

\section{Bankruptcy outcome decisions in the literature}

\subsection{French bankruptcy proceedings and the course of $R e$ - dressement Judiciaire}

To understand how Court's decisions affect bankruptcy, one needs to look at the two possible motives when filing for bankruptcy: terminating the firm seen as nonviable or pursuing its activity. Each country offers a menu of proceedings that correspond with these two motives: in the U.S. Chapter 11 for continuation and Chapter 7 for termination; in France, Redressement - around a third of all filings a year - or Sauvegarde ${ }^{10}$ and Liquidation - around two thirds of all filings a year ${ }^{11}$. Since 2015, Redressement as Liquidation needs the firm to be insolvent ${ }^{12}$ for less than 45 days (rather than 15 days before).

A judgment opening for Redressement must be settled within 12 months after filing. Exceptionally, it can be extended twice, for 6 months each time. A filing should not last more than 24 months without a decision from the court. As soon as the firm files into bankruptcy, the firm is in an automatic stay of payment until a decision is made by the Court. Automatic stay prevents the firm's situation to aggravate by stopping the reimbursements of its creditors. From the filing for Redressement, 7 out of 10 cases fail to

\footnotetext{
${ }^{10}$ Inspired by Chapter 11 , this proceeding only accounts for $1.5 \%$ of all proceedings a year. We choose to focus solely on Redressement.

${ }^{11}$ Source : Altares DEB

${ }^{12}$ Insolvency is defined in France as "the impossibility of being able to meet liabilities due from available assets".
} 
reorganize and are either converted into a Liquidation proceeding or even closed ; around 5 to $6 \%$ of firms end up sold as a going concern and around one-fourth manage to agree on a continuation plan ${ }^{13}$.

The statistics on the time required to reach an outcome after filing are reported in Table 3. They are in line with similar figures reported by Morrison 2007; Warren and Westbrook 2008 for U.S. cases. Indeed, the transition from a Redressement case towards a Liquidation happens fast: in half of the ases within 11 weeks. Such statement underlines that there is no waste of time with non-professional judges compared to professional ones.

From the filing, an administrator is appointed by the court - an administrateur judiciaire ${ }^{14}$. She replaces the firm's manager : she is in charge of the management of bankrupt firms ; she must at the same time supervise and control all the firm's actions. She reports directly her actions to the court (to a specific bankruptcy judge called juge commissaire). She also provides insight on the opportunity for the firm to be reorganized. A specific bankruptcy judge, the creditor representative (mandataire judiciaire), represents the creditors' interest, assesses proofs of claims, and can be assisted by supervising creditors (créanciers contrôleurs). Only the Court eventually decides a reorganization plan or, on the contrary, allows for the piecemeal liquidation or the sale of the firm. The bankruptcy process is completely "court-administered" (Blazy et al. 2011) and the creditors may at most be given a advisory role.

\subsection{Role and specifics of French bankruptcy judges}

Bankruptcy judges are not paid for their services. They voluntarily apply for the position when sponsored by an employer's association. the court is self-selected, the election is decided by sitting judges and members of the Chamber of Commerce of the local jurisdiction. This specific status is supposed to help them better understand business issues than would legal experts. We must stress out although they are elected, these non-professional judges follow a legal training and cannot sit in a bankruptcy Court until two years after their first election. They are first elected for two years then four years with at most four successive mandates.

Judges are competent on two fields: disputes and assisting distressed firms. The latter encompasses the prevention of bankruptcy and the bankruptcy process itself. The court is composed of three to five bankruptcy judges under the authority of a president, who is elected for four years among her peers. The court accepts the filing for bankruptcy, which initiates the bankruptcy process. It also selects if the firm can be reorganized or should be directly liquidated in case it is insolvent. After the observation period ${ }^{15}$, the court

\footnotetext{
${ }^{13}$ Source: ALTARES, L'entreprise en difficulté en France

${ }^{14}$ a numerus clausus profession

${ }^{15}$ Six months renewable twice
} 
will decide the fate of the firm (reorganisation, sale, or liquidation). The president remains the same but the other judges may change along these two decisions. The bankruptcy process is lead by an insolvency judge called juge commissaire. She will allow or forbid management decisions proposed by the firm's judicial administrator. All these judges are consular judges, even the president (except in Alsace-Moselle with its mixed courts as in Belgium), and their role can change depending on the case.

Their decisions can be challenged through the court of Appeal, where only professional judges sit. Yet these appeals are relatively infrequent (4.5\% of the $\operatorname{cases}^{16}$ ). This statistics is seen as a proof of the efficiency of bankruptcy Courts in deciding.

The key feature in terms of legitimacy is their proximity to business environment. Thanks to their experience, consular judges should be more likely to understand business problems than professional judges (civil servants) and to monitor the company's action, particularly in cases of financial distress (Carruthers and Halliday 1998). Their experience also allow them to understand specific industry customs (called usages in French commercial courts) which contribute to organizing business practice, but are often ignored in business law. Thanks to experience sharing, all judges are able to adapt to the specifics of each industry.

Consular judges are deemed "natural judges of the economy" by their own association (Conférence Générale des Juges Consulaires). To understand how important this representation is, one can refer to the interviews Lazega (2009) had with the Parisian consular judges. Though not equally shared, a large number of judges believe their judgments should preserve equity and fairness, and emphasize that they want their decisions to be practical. This opinion is enhanced by their business-affiliation which should grant them an "economic" point of view rather than a "legal" one, which should be reflected through their decisions (see the reported remarks of the judges p187-188 in Lazega and Mounier 2009). Obviously all judges do not share this line of thinking as many may have a strong connection with the law and thus are more likely to watch for its strict application. For example, twenty-four out of the one hundred and fifty one judges that Lazega and Mounier 2009 interviewed were jurists/bankers who displayed a strong knowledge in legal questions to the point that they advised their peers on some subjects.

\section{Identification strategy}

To test the motivations of bankruptcy judges, we focus on the decisions after the filing i.e. whether the court defends a continuation plan, the sale as a going concern or simply the liquidation of the firm. The model analyses

\footnotetext{
${ }^{16}$ Source : appeal rate in 1999 and 2000 for bankruptcy decisions ruled in 1999 Girod 2002
} 
successive transitions ${ }^{17}$. We face three main issues trying to tackle the effect of local environment. We need to separate the effect of the local economic context from economic changes, at the national or at an industrylevel. Also though the judges are similarly appointed, the jurisdictions may display many variations in size and culture. The last issue is that the timing of judgments is not entirely set beforehand and a decision to eventually liquidate a firm is taken more quickly than when the decision is to reorganize the firm.

The question raised requires many control variables of the decision by judges. Public information - available for all firms in the sample - is diverse. It gives the firm's age, its localization, its size (number of employees), its origin (as a new business for example) and its legal form. Several environment variables are used - some on an industry level, others at the macro level and finally two at the local level (unemployment rate and new firm creation rate). The firm's economic environment is mostly used to approximate the firm's future value. Various business-sector descriptors were used in the literature, market-wide - such as in Partington and Kim 2008 or in Hoi Fung Ng 2007; industry-wide such as in Ayadi-Ben Lakhal 2011 or even economic-wide such as in Gutiérrez, Olmo, and Azofra 2012. Here, we consider two economic variables - national growth and local new firm creation rate over the last three years - to check whether the effect of local unemployment on reorganization is not actually due to changes in the economy. We want to estimate the sole effect of unemployment rate under constant economic conditions. The local unemployment rate is given at the French department-level and is quarterly-based. The creation rate of firms at the department-level also is also computed over the last 36 months. It is a good proxy of the local activity dynamics and most past studies show that the delayed effect in bankruptcy of an increase in firm creation rate is to be expected after 3 years in France (Desurvire 2000).

For the industry-level variables, the Banque de France ${ }^{18}$ provides the evolution of many financial ratios over time. These ratios are average ratios dealing with profitability, the weight of labour and of debt but also the share of interest bearing debts in overall debt. The information on trade debt is not significant in our models. The ratios covers nine distinct business sectors on a yearly basis. Using these variables, we can assess whether a business sector is dynamic, and how bank-dependent it may be, which may also have an impact on the chances of reorganization. We also want to prevent the local unemployment effect to be driven by national changes.

\footnotetext{
${ }^{17}$ The possibility of a direct closure of the proceeding is also informed in the data but not interpreted here. This situation is a simple statement - the firm is found to have not enough asset to pursue its activity - there is relative no other possible decision from the court's perspective. Direct liquidation accounts for around two-thirds of the filings each year (Source: Altares).

${ }^{18}$ The French Central Bank
} 
Therefore, we perform the same analysis adding the national unemployment rate as covariate (see Table 14).

The last issue in tackling the local effect is the risk of structural changes in the bankrupt firms. Three years after the 2007 crisis, more and more large firms tend to file in bankruptcy because of cash shortfall, and the chances of reorganization are affected these changes in the nature of firms. The most efficient way to challenge this problem is to use financial information for each firm but they are available for half the firms in the population (see Table 1). In addition, these financial ratios are not equally available for all sizes of firms as shown in Table 10 : lack of financial information happens mostly to firms with no employees which display less financial information than the rest the rest of the population ( $28 \%$ vs. $53 \%$ on average). We test whether our results change by weighting the firms by size, by adding an interaction term in our model and we find that the results remain the same.

We also aim to assess whether the courts do not change their decisions process because of work-overload. If there is an increase in local unemployment rate, it may be due to an increase in the number of caseloads the court must face. We could think, inspired by Iverson 2017 that changes in judgment may be due to this stress. The judges decide to increase the time to decision and even choose the default alternative, i.e. the reorganization plan, to delay the shutting down of the firm. To check for potential increase in bankruptcy filings, we add the number of past proceedings in the last 12 months. And we assess a bias toward default decision by looking at the survival of the firm after a reorganization plan was agreed upon.

The main reasons for choosing survival analysis over the usual logistic regressions are to take into account censored data, i.e. firms for which judicial decisions are still lacking, and to show the effect of covariates on the duration of the proceeding. Though extended to a six-year horizon, the time-coverage is not enough to follow all filings from onset to closure, a reorganization plan generally lasting for 10 years. All other statistical models would need assumption on these observations and thus would bias the results. We choose a competing risk setting ${ }^{19}$ rather than the more often used mortality model (Hougaard 1999) with only one possible outcome, survival versus failure (e.g. Denis and Rodgers 2007; Hoi Fung Ng 2007). Competing risk suits more the trajectory in a judicial path. In such setting, the termination date of a process is not reduced to the transition to a single event but rather to the transition from a state to another among different choices. Competing risk setting assumes a competition between the alternatives. Indeed, there is a competition in the possible duration of each alternative: after filing, creditors, suppliers, customers and even employees do not know whether the firm will be continued, sold or liquidated ; the higher the chances of liquidation, the less time a firm would have to offer a suitable reorganisation

\footnotetext{
${ }^{19}$ see Lancaster 1992; Hougaard 1999; Beyersmann, Allignol, and Schumacher 2012.
} 
plan.

This setting also increases the explanatory power of the effects of the covariates on each alternative (Beyersmann, Allignol, and Schumacher 2012; Astebro and Winter 2012 in the case of bankruptcy). This effect would be blurred by a two-alternative model opposing closure to survival. For instance, the size of the firm, is known to influence the decision in different ways: the chances to agree on a continuation plan increase with the firm's size until a threshold where the firm is most probably sold. Competing risk setting has already been used to study the aftermath of French reorganization plans (Ayadi-Ben Lakhal 2011) to determine whether the firms end up being sold, closed or if it manages to survive. We were inspired by this work when we tested the survival of the firm after it agrees on a continuation plan.

Table 1: Breakdown of events for financial information availability

This table provides the breakdown of events depending on available financial information in the 24 months before filing for bankruptcy. More than half of firms display financial information.

\begin{tabular}{l||c|cc} 
& Obs & No financials & Financials \\
\hline Censored & 4,133 & $35 \%$ & $65 \%$ \\
Liquidated & 34,157 & $57 \%$ & $43 \%$ \\
Closed & 10,054 & $56 \%$ & $44 \%$ \\
Sold & 3,192 & $23 \%$ & $77 \%$ \\
Plan & 14,363 & $27 \%$ & $73 \%$ \\
\hline Total & 65,899 & $47 \%$ & $53 \%$
\end{tabular}

To challenge these questions, we use a Cox model. It models the hazard rate, i.e. the probability to leave some state at a specific time knowing you were still in this state. It models an instantaneous probability of switching states. The main reason to choose a Cox model is its simplicity in modeling: we assume two components in the hazard rate, a non-parametric part called baseline hazard, $\lambda_{O j}(t)$ and a parametric component that depends on the covariates, Z.

$$
\alpha_{0 j}(t)=\lambda_{0 j}(t) \exp (\beta Z)
$$

Despite simplicity, the model makes a strong assumption, the Proportionality Hypothesis which states that the relative hazard rates of two different individuals is solely explained by the parametric part of the model. The difference in hazard rate ${ }^{20}$ between two firms only depend on the variables tested in the model. In equation, this means that for $(k, l)$ two different individuals, we have:

\footnotetext{
${ }^{20}$ The hazard rate considered only models the transition towards the same alternative, i.e. from the filing to a continuation plan or to liquidation.
} 


$$
\frac{\alpha_{(0 j, k)}(t)}{\alpha_{(0 j, l)}(t)}=\frac{\exp \left(\beta Z_{k}\right)}{\exp \left(\beta Z_{l}\right)}
$$

The court's dummy variables deviate from this assumption. This means that the court's effect from one court relative to another vary over time. One explanation of this issue is differences in organisation. French bankruptcy courts can be composed by nine judges (like in Saverne, Ajaccio or Gap in 2014 ) to 172 judges (in Paris) ${ }^{21}$. Such changes in size have implications all along the course of the bankruptcy. To resolve this issue, we stratified with the courts as strata. Each non-parametric part of our Cox model differs for each Court. This also allows us to assume that each Court may have different timing because for example of differences in size. Let us recall that Paris Commercial Court saw 7\% of 2013 filings while the 44 smallest Courts represented only $10 \%$ of all filings. The drawback of this model is the risk of a decrease in the significance of coefficients.

Inspired by the local legal culture, we test for different "trends" in the court's decisions. We question whether some decision patterns may be accounted for, asking if a Court that enforces more reorganization proceedings than liquidations tend to judge differently a bankrupt firm. To identify a possible rescuing culture in each Court, we compute the share of direct Liquidation in the number of filings and the share of Sauvegarde. We assume the share of direct Liquidation is a good proxy of the relative punitivity versus interventionism culture in the court (see Lazega and Mounier 2009). The more the court accepts that firms file for reorganisation (instead of direct Liquidation), the more it seems ready to intervene on bankruptcy.

Survival analysis also allows for inclusion of unaccounted effects in each subgroup, with a shared-frailty model (Hougaard 1999; Rondeau and Gonzalez 2005). It is well suited in cases of different centers of trials with possible different performances of each center. As such, the model fits well our goal to understand the weight of the local environment. Such model is particularly useful for assuming unobserved heterogeneity inside the clusters, e.g. the trial centers. By clustering, the models allows for autocorrelation between the errors inside the cluster. It is convenient for our analysis since we implicitly assume that judgments affect each other in each Court.

Shared-frailty models use a parametric multiplicative component in the hazard rate. The underlying idea is to model a random effect that affect the observations because of clustering issues, e.g. it may be pupils belonging to schools with different characteristics or patients with doctors of different skills. The method has been debated for a systematic use but is well performing to check for these common effects on the individuals.

This complements our set of Court characteristics and the variance of the random effect gives us insights on the extent to which the court's characteris-

\footnotetext{
${ }^{21}$ Source : Conférence générale des juges consulaires
} 
tics explain the decisions. The higher its variance, the more the cluster effect explains the evolution of the hazard rate. The results are reported in Table 13. The heterogeneity effect is assumed to follow a Gamma distribution of $\omega$ parameter. Due to this assumption these models are also more sensitive to correlation issues than the original Cox models. Because of this, we took out from the modeling the number of past filings. The parametric assumption in the heterogeneity forces us to use it as a complementary approach to validate the effect of local unemployment rate. We add a frailty, $\omega_{i}$, for each Court $i$. The frailty $\omega$ is supposed to follow a gamma distribution. Formally, the hazard rate - assuming a similar form than in a Cox model — can be written as follow.

$$
\alpha_{0 j}(t)=\lambda_{0 j}(t) \omega_{i} \exp (\beta Z)
$$

The last concern in our identification strategy is the discrepancies in length between outcomes after the filing. While the average time for a firm to be shut off or liquidated is 20 weeks, it takes around 50 weeks to decide on a reorganization plan. This is mainly because of the bargaining issues that are implied with such a plan. In other words, finding a consensus to support the plan takes time. Because of this, the environment at filing may not be the one that defines the judges' decision. The court must reunite after 12 months to decide on the opportunity of the reorganization, and again every 6 months, up to twice, if no decision was reached. That is why the state of the economic environment at each meeting must better explain the decisions, especially if it takes one year for a plan to be agreed upon, rather than the economy at the filing. Yet we have no information on the moment the courts meet again on each case.

Survival analysis is really flexible with timing issues and allows one to model the effect of time-dependent covariates. From the filing, we take into account the environment of the firm every three months until a decision is reached and we update the values of the environment covariates : variation in GDP, unemployment rate and creation rate. This is allowed by survival analysis since we can "cut" the time process and consider that the observation is censored until the time of the event is reached. We will use time-dependent coefficients in all our models after a first check of the effect of the covariates at filing (see Table 16).

\section{Data and summary statistics}

In this section, we describe the sources of our data (4.1) and display summary statistics on our sample with breakdowns by outcomes, size, financial information availability (4.2). 


\subsection{Sources}

The data are drawn from all French jurisdictions. It covers all Redressement Judiciaire filings after the 2006 reform of bankruptcy law to 2013.

Data following bankruptcy from their onset are scarcely found. Two limits can be generally found in the literature: year-selection or sample selection. In the first case, only a few years of filing are analyzed in particular (Morrison 2007 or Warren and Westbrook 2007 and Warren and Westbrook 2008 or Levratto, Tessier, and Zouikri 2011) covering a longer period with the risk of strong bias selection depending on the economic climate. A few paper cross-analyzes several subsequent years, such as Denis and Rodgers 2007, Hoi Fung Ng 2007 or Ayadi-Ben Lakhal 2011. Their downward is then the limits of their sample which is either focused on a single jurisdiction (Paris for AYADI-BENLAKHAL2011, Chicago for Morrison 2007) or on a short sample - only listed companies for Denis and Rodgers 2007; Hoi Fung Ng 2007.

In France, three potential legal sources can provide information on bankruptcy proceedings. ALTARES-D\&B provided all events registered by these data sources - the official bulletin of civil and commercial notices (BODACC), the National Commercial Registry (RNCS) and legal notices ${ }^{22}$. For the economic variables at the macro and department level, we used information provided by INSEE. The GDP growth is computed over 12 months on a monthly basis and the national unemployment rate computed on a quarterly basis.

The study is concerned with all commercial firms ${ }^{23}$. Ten business sectors $^{24}$ are selected for the study. They encompass all the productive sectors. Only public services, the art industry, the food industry and the financial services were ruled out. The latter two - though important - cannot be treated because of differences in accounting and in the bankruptcy process.

Most of the available information on firms is given either by the national census bureau - Institut National de la Statistique et des Etudes Economiques (INSEE) or the commercial registry. The financial variables are given with the balance sheet. Though mandatory for most firms, more than half do not publish them and it specially depends on their size and their business sector ${ }^{25}$. The availability of financial information can bias the

\footnotetext{
${ }^{22}$ ALTARES-D\&B also crosschecks the consistency of each legal notice.

${ }^{23}$ We have excluded sole proprietorship, i.e. entrepreneurs without a distinct legal person

${ }^{24}$ To derive this, we use the sections of activity code proposed by the French census bureau, the NAF code. We select Manufacturing, Construction; Wholesale \& Retail; Transportation \& Storage; Accommodation \& food services; Information \& Communication; Real estate activities; Administrative \& support activities; Education; Arts, entertainment \& recreation industry; Energy, Water, Waste management.

${ }^{25}$ For instance wholesalers or supermarket chains would rather avoid sharing their margins and as such seldom publish.
} 
results. The firms with available balance sheet tend to have lower default rates and higher chances of survival after default.

We have decided to add the firms with balance sheet as old as 24 months before the filing. This is in line with most bankruptcy scoring analyses. We use the information provided by Altares-D\&B. As shown in Table 7, half of balance sheet were less than 11 months old at the time of filing and the three fourths are 16 months old.

\subsection{Summary statistics}

The characteristics of firms filing for reorganization resembles the French overall firms. Four out of five firms have fewer than 10 employees and the most common legal form is firm with limited liability company. Most of the time, the courts face small firms and most probably local businesses but most of them still have employment issues. As we can see in table 5, 60\% of the firms have between 1 and 10 employees. The decision to liquidate the firm will have an impact on employees, local unemployment, and will affect the court's environment. Because of their daily jobs, bankruptcy judges are in direct contact with this reality.

Looking at the statistics by business sector in Table 9, the firms in the sample do not show many differences except for the Manufacturing sector. The discrepancies rather lie within the size of the firms as shown in Table 10. Only two-thirds of the firms with financial information have less than 10 employees vs. nearly three quarters for the whole population.

More than half firms with more than 50 employees have a balance sheet available. The availability of a balance sheet is the proof of a sound situation, which can be explained by size issues. The firms with available balance sheet are larger and may show a survival bias. The second sample will be used to confirm insights obtained with the whole population.

We use common ratios and accounting measures to take into account the situation of the firm. We include measures of profitability (profitability margin), of size (the logarithm of total assets), of trade debt (logarithm of payables). Table 7 shows how poor-performing most bankrupt forms are by looking at their profitability margin : only $25 \%$ of the firms have their profits above $2 \%$ of their turnover. Looking at the standard-deviations, they also widely differ in size, in their trade debt but also in their amount of fixed assets.

\section{Econometric analysis}

As shown in the summary statistics, the firms with available financial information present a selection bias. To solve this bias, our analysis proceeds in two steps. We check for all the main options - reorganization plan (1), sale as a going concern (2) or liquidation (3) - first on the whole population (a) 
and then on the sample with available financials (b). The second test is thus a checkout from the first conclusion taking into account that the impact of some covariates can evolve along the time of the bankruptcy. For example, the profit margin of the firm could be important only at the filing; or it could be a good proxy of the profit margin along the bankruptcy process. We thus try to better replicate the set of information upon which the judge decides. We first test on the value of covariates at filing; then using a time-dependent model, we test the same model, the same plus the national unemployment rate and also a shared-frailty assumption on the courts ; then we look at the differentiated effect of the protection by an interaction of the unemployment rate and the size of firms. The interaction with the size of firms can tell us whether the bankruptcy judges adapt their response to local economic turmoil depending on the firm's size. The bigger the firm, the more impact its liquidation would have. We conclude analysing the effect of the unemployment rate on the survival of the reorganization plan.

Our tables list the coefficients of the Cox model. In order to make our interpretations easier, we will compute hazard ratios in our analysis by taking the exponential of the parameter estimates. If the coefficient in the table is equal to $b$, its hazard ratio is $\exp (b)$ and its effect on the outcome is $\exp (b)-1 \%$. Looking at Table 16, the coefficient of Forum shopping on the reorganization plan event is -0.063 and $\exp (-0.063)=0.939$. Thus the impact of forum shopping on the reorganization plan after filing is $6.1 \%$.

\subsection{Testing with variables at the time of filing}

We start our analysis with the simplest model, i.e. with the values of all variable at the time of filing (Table 16). In this setting no environment plays a significant role in both samples except for the local unemployment rate. We analyse this effect and comment in extenso the coefficients of the other covariates since they remain mostly the same through all the other tests.

In both samples local unemployment rate displays the same sign and level of significance - at the $5 \%$ level at least - to explain transition towards reorganisation plan. This results holds despite the number of controls: an increase of one point of local unemployment rate means an increase of $4.4 \%^{26}$ in the chances to agree on a continuation plan $(3.7 \%$ for firms with financial information). In parallel, an increase in local unemployment rate also implies an increase in the chances to liquidate the firm but with lesser magnitude ( $1.4 \%$ in the whole population and $2.2 \%$ in firms with financial information). To sum up, the local unemployment rate delays both decisions but the higher magnitude for the reorganization plan indicates a shift in distribution of events. The two Cox models show that the decision of Courts are truly affected but it is overall in favouring reorganization plans and to avoid sale

\footnotetext{
${ }^{26}$ In the rest of the paper I indicate the hazard ratios rather than coefficients since it indicates the effect in term of probability
} 
as a going concern. The increase of the hazard rate of Liquidation can be explained relative to the sale as going concern. Local economic turmoil probably discourages potential buyers, with less business opportunity at the time. It should also limit credit lending to finance these acquisitions.

We then analyse the coefficients of all the other time-invariant covariates. The effect of size is in line with what we expect from other studies on the French case (see Blazy et al. 2011 or Levratto, Tessier, and Zouikri 2011). The bigger the firm, the lesser chances the attempt to reorganize the firm fails, meaning the reorganization proceeding ends up converted to a Liquidation. The coefficients are particularly strong and significant for the whole population - the decrease in chances reaches $65 \%$ for firms with more than 250 employees - yet they drop at a constant level for the population with financials - chances to being liquidated drop of about $20 \%$. This may be due by our taking into account the financial information and in particular the total assets but also because of the scarcity of balance sheet available for firms with no known employee. The effects for the two other alternatives, the reorganization plan and the sale as a going concern, are not linear but complementary. They are the easier to read for the population with financials. The firms that have the greatest chances to agree on a continuation plan are those with between 1 and 10 employees (14.9\%) and those with more than 250 employees (62.5\%). While the firms "in between" from 10 to 249 employees are the more likely to be sold as a going concern. It is only logical, external growth is the more feasible for mid-size firms big enough to reach their breakdown point without being too hard to integrate.

Financial information have same coefficients as expected. The profitability margin increases strongly the chances to agree on a reorganization plan $(28 \%)$ and to sell the firm as a going concern (30.8\%). The effect is negative but non-significant on the risk of Liquidation which should be explained by the high level of distress looking at at the distribution of level of profitability margin in Table 7 . It is also worthy to note that the trade debt actively plays a role only for the chances to sell the firm with an increase of $6.7 \%$ and decreases the chances of liquidation $(-4.9 \%)$. It seems fair that junior creditors want to avoid at all costs that the firm disappear since their recovery would be less plausible. On the other hand, a firm that supplies an important debt to the bankrupt firm would value the latter all the more. The impact of wages seems coherent with the results by Blazy et al. 2011 . We assume weight of wages to be a proxy for labour-intensity. The more labour-intensive the firm, the less the judges prone to sell the firm with the risk of layoffs. Also, the value of the firm may depend more on its human capital, and thus make its valuation more difficult. Finally the volume of fixed assets is only favorable for the reorganization plan $(1.9 \%)$ and plays negatively on the sale as going concern $(-6.5 \%)$ but above all on the risk of liquidation $(-14 \%)$. If the firm has managed to keep a large volume of fixed assets, i.e. its investments, it has most probably an important bargaining 
power vis-a-vis its debtors.

The effect of the size of total assets could be ambiguous. The bigger the firm, the more important the firm may be in the local economy of the jurisdiction. But a large number of assets in a distressed firm may complicate its reorganisation. The risk of being liquidated $(8.6 \%)$ or sold as a going concern (45\%) increases with the volume of assets while the chances to reorganize actually decreases. Since we also control for the volume of fixed assets and trade debt, we mostly take into account here goodwill and current assets less trade debt. The size of the coefficient on the eventuality of sale may be because the bigger the firm, the more undervalued these assets can be ; also insider management may need help from outsider investors to put into motion a reorganization.

Last our data provide information on Forum Shopping, i.e. being judged by another Court than the one the firm is registered to. To interpret the covariate, one should wonder what would have happened if the firm had been judged by its reference Court. The only consistent effect on both samples is a strong increase in the risk of liquidation $(15 \%$ for the whole population ; 18 $\%$ for firms with financial information). The impact on the eventuality of a sale is only found in the whole population $(+30 \%)$. Since it is not significant when we can control for it with financials, we can infer that Forum shopping is mainly used by the larger firms, the more concerned by the sale as going concern.

\subsection{Testing for time-dependent covariates}

Conversely to the previous time-invariant model, once we allow for the environment variables to vary with time, they all have an incidence on the decisions. The first result is that the effect of local unemployment remains the same in terms of magnitude and significance level as in the model with the values at filing. As shown by comparing the table 16 with table 12, the changes stem from the significance level of the other environment variables. The coefficients associated with the variation in GDP growth are negative and significant to explain both reorganization plan and liquidation. Yet the coefficient is stronger in the latter event (5\% vs. 3.7\%) and even increases when we control for financials (10\%). It is easier to read this effect considering a drop in GDP growth. A decrease in growth implies that the proceeding lasts longer before reaching these two events but the detrimental effect of bad times predominates over the possibility to reorganize the firm.

The only puzzling coefficient is the effect of firm creation rate on the whole population which is strongly negative $(-19 \%)$ and significant. But this figure becomes mildly positive $(1.8 \%)$ and not significant when we test with the financial information.

As mentioned in the first section, Cox model can add a multiplicative component in order to take into account heterogeneous unobserved effects 
based on a cluster, here each Commercial Court. Because of correlation issues with this clustering assumption, we take out from the covariates the number of bankruptcies in the past 12 months. The results underline the existence of a local legal culture and the need for considering it to explain decisions (Sullivan, Warren, and Westbrook 1994). It also stresses a differentiated effect of the local unemployment rate.

Shared frailty models allows for testing the robustness of the intraclass correlation, i.e. the relevance of the clustering assumption and the explaining power of the heterogeneous effect of each Court. As shown in table 13, for all transitions the variance is found to be significant. Its magnitude varies with each transition and remains stable testing on the whole population or controlling with financial information. It has the strongest effect when it explains the agreement upon a reorganization plan (68\% for the population; $56 \%$ for firms with financial information) ; it has a lesser effect on the sale as a going concern $(14 \% / 13 \%)$ and weakly explains the risk of Liquidation $(3 \%)$. According to these results, there is a huge disparity on the firm that are allowed to reorganize ; it is then that the disparities between courts display the most importance ; while the decision to shut down a firm relies on the same rationale everywhere.

The environment variables are in line and of the same order of magnitude as those describe before except for the effect of the local unemployment on the transition towards Liquidation in sample (b). The effect is smaller $(0.6 \%)$ and no longer significant.

\subsection{Checking the effect of local unemployment rate}

In order to clarify whether these decisions are local deviations, we derive a simple test by adding both national and the gap between local and national rates. Results are reported in table 14. They confirm that the main determinant driving reorganization plan is local. The national rate displays no significant effect on the first outcome, i.e. the reorganisation plan. The gap between unemployment rates display similar coefficients to the ones displayed before. This confirms that local changes are the main motives behind the effects that we document.

On the other hand, Liquidation is strongly and only affected by the national unemployment rate (31.9\% for the whole population $/ 44.6 \%$ for firms with financial information). The effect is thus proven stronger when we take into account the financials of the firm while the variation in GDP remains significant. These results indicate that the national unemployment rate stands probably as a better proxy of the general economic context and its effect on the perspectives of the firm as seen by the court. The judges can adapt their decisions at a local level. They do not force reorganization of firms when the overall economy worsens, proxied here by an increase of national unemployment rate. This can explain why Marinescu 2011 finds that an increase in 
this rate boosts decision against the employees. They adapt their decisions but are not myopic about the consequences. This is confirmed latter on when we test the interaction of local unemployment and size (see Table 15). For the sale transition, the coefficient of the national unemployment rate is highly negative and this result is consistent with our first model. Only the agreement on a reorganization plan displays distinguishing results.

We now check whether Courts behave differently depending on the firm's size in the spirit of Blazy et al. 2011, who showed that the choice in buying offer was directly affected by the number of employees. We wonder whether the concern on local unemployment differs and increases with the firm's size. To do so we consider the interaction term between the rate and the size of the firm.

The interpretation of interaction terms on Cox models is not straightforward. The impact of an increase of $n$ points of the unemployment rate on firms with 10 to 50 employees should be $\beta_{\text {unemployment }}+\beta_{\text {unemploymentx } 10-50 \mathrm{empl}}$. The results are reported in the Table 15 .

There are multiple lessons. There is no clear effect of the local unemployment rate on the risk of Liquidation if we look at both population and sample with financials. The significance of the coefficients for the whole population drop to zero when we control for financials. An increase in local unemployment should only raise the risk of Liquidation for the firms with more than 250 employees but the interaction term is not significant. Concerning the sale as a going concern we can only see a significant increase on the whole population for the interaction term of the firm between 50 to 250 employees $(+3 \%)$, this effect remains true for the sample (b) but is no more significant.

The most striking result concerns the chances to reorganize. The coefficient of the local unemployment is now negative - though not significant for sample (b) - but it must be interpreted with the addition of the interaction terms. We thus found that the effect is overall on firms between 1 to $49 \mathrm{em}-$ ployees, the level of the sum of these coefficients is similar to what we found before (around 3\%). The effect for larger firms is less clear. Looking at both samples, it appears to be null but also not significant. These findings can be interpreted through the local concern of the courts. It is most plausible that larger firms do not work in the sole perimeter of the jurisdiction but above all can easily benefit from a national, media or political, concern. The firms between 1 to 49 employees are the most locally embedded and those that would benefit the most from these deviations.

\subsection{Testing for the survival of prolonged firms after a reor- ganization plan}

We reckoned that the effect of the local unemployment is most probably timedependent. Furthermore the interpretation of the coefficients is to check the effect of an increase relative to the average local unemployment rate between 
all the courts, not within each court. We thus derived a new variable to test for the deviations from an increase in local unemployment. We look at the gap between the actual rate and its mean value for each Court over the 6 years under study. We find no effect on the failure of the firms. This new variable was motivated by the absence of effect when we used the local unemployment rate alone. Also we attempt to take into account that the effect of the unemployment rate is the highest at the time of the continuation plan. To do so, we propose a second model (2) where we consider each of the quarterly observations we used for the time-dependent model. We then look at the chances of survival knowing these firms are the ones to get a continuation plan. In order to decrease the autocorrelation issue, we cluster the observation by firm (using its SIREN number).

In both models we look at the time before the decision following Beyersmann, Allignol, and Schumacher 2012 on multi-stage models. But the coefficient though significant in the model has no effect on the risk of failure. Only three variables in our testing have a real impact and hamper the risk of failure after a reorganization plan: the profitability margin (around -20\%), the size of the firm in terms of assets (around -10\%) and the decision to Forum Shopping (between $-16 \%$ and $-25 \%$ ).

\section{Conclusion}

The local unemployment rate proved to affect the decision of French bankruptcy courts after a firm has filed into Redressement Judiciaire and this result is confirmed even after we run a number of tests done throughout the paper to control any issue arising. It is most probably the result of Courts being not only auditor of bankrupt firms but also political institutions of their jurisdiction. As such, they cannot prevent their decision to be politically charged and to overcome a simple conflict resolution to try to being concerned with non-investors. They are inclined to do so because of two features provided by French law: they are elected among professionals from their jurisdiction and they have a key role of French Courts in the bankruptcy process.

The consequences of the changes in local unemployment are to hasten the decisions and increase the chances of a reorganization plan. One of the two involved parties signing the reorganisation plan must have been invited by the Court to do some effort on the recovery rates provided in the plan. Also, these deviations resulting from the local context have no apparent consequences on the firm's survival. Both results should imply that the firm's creditors agree on cuts of recovery rate. The question these results raises is whether these deviations are beneficial or not for the economy in general. If the creditors are mostly other local businesses, such write-offs may increase the risk of a domino effect. This fear may explain why we found a differentiated effect of the unemployment rate depending on the size of 
firms. The interaction term is the highest and the most significant for firms with fewer than 50 employees. If the creditors are mainly national banks, the consequences may be unclear at a local level but the cost of credit should probably increase. The cost/benefit analysis of this impact seems hard to evaluate due to the lack of $d$ data.

Our most striking result is the lack of effect on the survival of prolonged firms. This result resembles the findings by Blazy et al. 2011; LoPucki and Doherty 2007 on the effect of bankruptcy outcome on the global recovery rate. Yet we may have limited information on the subject since a reorganization plan generally lasts over 10 years. Moreover we are only concerned in this paper with the firm's survival, not its performances. Maybe the firm is under-performing with an increased risk of recidivism later on, i.e. filing again for bankruptcy.

The significant impact of local economy proves that courts are obviously embedded in the local economic tissue. They are driven by other motives than the enforcement of law alone or the trade-off between going concern and liquidation values. These findings are all the more concerning at a time of bankruptcy reform, especially since they tend to inspire from Chapter 11 which gives an important weight to the court. For instance, Germany and Spain have inserted "cram-down" procedures, i.e. the possibility for courts to force their decisions, and thus have heightened the latter's power. France is also currently debating its future reforms. As shown in the MP mission, there are big concerns on which structure of bankruptcy court to favor; the need for professional judges rather than only local professionals was in question.

These results are also linked with the French situation and the weight of Court in the decision. Yet local variables may still remain significant in systems (such as the English one) where Courts are limited to an auditing function. For instance, creditors with many businesses on a certain perimeter such as a regional bank should also be aware of the local climate. Thus, they must also care not to propagate financial difficulties among their customers. Therefore, there is a need for testing these assumptions on different legal systems and to check whether the characteristics of French judges really explains the absence of effect on the firm.

\section{References}

Astebro, Thomas and Joachim K. Winter (2012). "More than a Dummy: The Probability of Failure, Survival and Acquisition of Firms in Financial Distress". In: Eur. Manag. Rev. 9.1, pp. 1-17. ISSN: 17404754.

Ayadi-Ben Lakhal, Rim (2011). "Reorganization of Bankrupt Firms in France : Financial and Econometric Analysis". PhD thesis.

Ben-Ishai, S and SJ Lubben (2011). "A Comparative Study of Bankruptcy as Bailout". In: Brook. J. Corp. Fin. Com. L. 
Beyersmann, Jan, Arthur Allignol, and Martin Schumacher (2012). Competing Risks and Multistate Models with R. Springer.

Blazy, R. et al. (2011). "Employment Preservation vs. Creditors' Repayment under Bankruptcy Law: the French Dilemma?" In: International Review of Law and Economics.

Blazy, Régis and Bertrand Chopard (2012). "(Un)secured debt and the likelihood of court-supervised reorganization". In: European journal of law and economics 34.1, pp. 45-61.

Carruthers, Bruce G and Terence C Halliday (1998). "Rescuing business: The making of corporate bankruptcy law in England and the United States". In:

Denis, Diane K and Kimberiy J Rodgers (2007). "Chapter 11: Duration , Outcome, and Post-Reorganization Performance". In: J. Financ. Quant. Anal. 1, pp. 101-119.

Desurvire, D. (2000). Histoire de la banqueroute et faillite contemporaine. L'Harmattan.

Ferriell, J. and E.J. Janger (2013). Understanding Bankrupcty. Lexis Nexis.

Frost, C. W. (1995). "Bankruptcy Redistributive Policies and the Limits of the Judicial Process". In: N.C. L. REV.

Girod, Paul (2002). Rapport $n \hat{A} \check{r} 178$ Projet de loi relatif aux tribunaux de commerce. Tech. rep. Sénat.

Gutiérrez, Carlos Lopez, Begoña Torre Olmo, and Sergio S. Azofra (2012). "Firms' performance under different bankruptcy systems: a Europe-USA empirical analysis". In: Account. Financ. 52.3, pp. 849-872.

Hoi Fung Ng, Calvin (2007). "Unravelling a twisted tale : A deconstruction of Cox's proportional hazards model and an inquiry into its ability to predict the outcome of Chapter 11 bankruptcy proceedings". PhD thesis.

Hougaard, Philip (1999). "Fundamentals of survival data." In: Biometrics $55(1)$.

Ichino, A., M. Polo, and E. Rettore (2003). "Are Judges Biased by Labor Market Conditions?" In: European Economic Review, pp. 913-944.

Irwin, John F and Daniel L Real (2010). "Unconscious influences on judicial decision-making: The illusion of objectivity". In: McGeorge L. Rev. 42, p. 1.

Iverson, Benjamin (2017). "Get in line: Chapter 11 restructuring in crowded bankruptcy courts". In: Management Science 64.11, pp. 5370-5394.

Iverson, Benjamin et al. (2019). "Learning by Doing: Evidence from Bankruptcy Judges". In:

Kang, Jerry et al. (2011). "Implicit bias in the courtroom". In: UCLa L. rev. 59, p. 1124.

Lambert-Mogiliansky, A., K. Sonin, and E. Zhuravskaya (2007). "Are Russian commercial courts biased? Evidence from a bankruptcy law transplant". In: J. Comp. Econ. 35.2, pp. 254-277.

Lancaster, Tony (1992). The Econometric Analysis of Transition Data. 
Lazega, E. (2009). "Four and Half Centuries of New (New) Law and Economics". In: Law's Environment: Critical legal perspectives, pp. 179-204.

Lazega, E. and L. Mounier (2009). "Polynormativité et contrôle social du monde des affaires : l'exemple de l'interventionnisme et de la punitivité des juges du Tribunal de commerce de Paris". In: Droit et Société.

Levratto, Nadine, Luc Tessier, and M Zouikri (2011). "Small, alone and poor: a merciless portrait of insolvent French firms, 2007-2010".

LoPucki, L.M. and P.W. Doherty (2007). "Bankruptcy fire sales". In: Michigan Law Review, pp. 106-160.

Lyon-Caen, A. and Q. Urban (1990). Le juge et la décision de gestion. Decitre.

Marinescu, I. (2011). "Are Judges Sensitive to Economic Conditions? Evidence from U.K. Employment Tribunals". In: Industrial and Labor Relations Review, pp. 673-698.

Montebourg, A. and Colomber F. (1998). Tribunaux de commerce, une justice en faillite. Michel Lafon.

Morrison, Edward R (2007). "Bankruptcy Decision Making : An Empirical Study of Continuation Bias in Small-Business Bankruptcies". In: J. Law Econ. 50.May.

Partington, Graham and M Kim (2008). "Modeling Bankruptcy Prediction using Cox Regression Model with Time-Varying Covariates".

Posner, R (1993). The Problems of Jurisprudence. Harvard University Press.

Rondeau, Viriginie and Juan R. Gonzalez (2005). "FRAILTYPACK: a computer program for the analysis of correlated failure time data using penalized likelihood estimation". In: Computer methods and programs in biomedicine 80.2, pp. 154-164.

Sharfman, Keith (2004). "Judicial Valuation Behavior: Some Evidence from Bankruptcy". In: Fla. St. UL Rev. 32, p. 387.

Shleifer, A. (2012). The Failure of Judges and the Rise of Regulators. MIT Presse.

Sullivan, TA, E Warren, and JL Westbrook (1994). "The persistence of local legal culture: Twenty years of evidence from the federal bankruptcy courts". In: Harv. JL Pub. Pol' y, pp. 1-76.

Warren, E. (2004). "Bankruptcy Policy Making in an Imperfect World". In: Mich. L. Rev. Pp. 574-75.

Warren, Elizabeth and Jay Lawrence Westbrook (2007). "Chapter 11: Conventional Wisdom and Reality". In: Public Law and Legal Theory Research Paper No. 125.

- (2008). "The Success of Chapter 11: A Challenge to the Critics". In: Mich. L. Rev. Pp. 603-642.

\section{Appendix}




\subsection{Descriptive statistics}

Table 2: Breakdown of events after filing by size (empl.)

The table displays how censoring and choices between events is affected by the firm's size.

\begin{tabular}{l||c|ccccc} 
size. & Obs. & Cens. & Liquid. & Closed & Sold & Plan \\
\hline No empl. & 1283 & $9 \%$ & $65 \%$ & $15 \%$ & $2 \%$ & $10 \%$ \\
Btw. 1 \& 10 empl. & 40188 & $6 \%$ & $52 \%$ & $16 \%$ & $3 \%$ & $24 \%$ \\
Btw. 10 \& 49 empl. & 11211 & $6 \%$ & $41 \%$ & $14 \%$ & $13 \%$ & $27 \%$ \\
Btw. 50 \& 249 & 1497 & $5 \%$ & $32 \%$ & $11 \%$ & $30 \%$ & $21 \%$ \\
Above 250 empl. & 168 & $6.5 \%$ & $24.4 \%$ & $6.5 \%$ & $41.7 \%$ & $21 \%$ \\
\hline Total & 65,899 & $6 \%$ & $52 \%$ & $15 \%$ & $5 \%$ & $22 \%$
\end{tabular}

\section{Table 3: Length (in weeks)}

The table displays information on the financials used in the tests. The "length in months since financials" show these information remain valid for analysis. $75 \%$ are less than 16 months old. All ratios have been winsorized at the $1^{\text {st }}$ and $99^{\text {th }}$ centile because of asymptotic issues.

\begin{tabular}{l||c|ccccc} 
& Obs. & Mean & Median & Q1 & Q3 & sd \\
\hline Censored & 4,133 & 49.06 & 31.00 & 10.57 & 48.00 & 72.53 \\
Liquidated & 34,157 & 20.61 & 11.43 & 7.86 & 28.00 & 19.98 \\
Closed & 10,054 & 20.37 & 12.00 & 8.00 & 27.43 & 19.09 \\
Sold & 3,192 & 28.69 & 23.93 & 13.43 & 39.86 & 19.45 \\
Plan & 14,363 & 58.08 & 55.00 & 51.00 & 65.00 & 14.23
\end{tabular}


Table 5: Summary statistics for categorical variables

The table displays information on the financials information used in the tests. The "length in months since financials" show these information remain valid for analysis. $75 \%$ are less than 16 months old. All ratios have been winsorized at the $1^{\text {st }}$ and $99^{\text {th }}$ centile because of asymptotic issues.

\begin{tabular}{l||c|cc} 
& Obs. & \% Obs. & Occurences \\
\hline Dependent variables & & & \\
Evt:Censored & 65,899 & 0.063 & 4,133 \\
Evt:Liquidated & 65,899 & 0.518 & 34,157 \\
Evt:Closed & 65,899 & 0.153 & 10,054 \\
Evt:Sold & 65,899 & 0.048 & 3,192 \\
Evt:Plan & 65,899 & 0.218 & 14,363 \\
\hline Controls & & & \\
Orig.:Creation & 65,899 & 0.643 & 14,646 \\
Orig.:Purchase & 65,899 & 0.133 & 8,737 \\
Orig.: Other & 65,899 & 0.222 & 14,646 \\
Legal:LLC & 65,899 & 0.884 & 58,287 \\
Legal: LLC with Board & 65,899 & 0.027 & 1,753 \\
Legal:Simpl. LLC & 65,899 & 0.081 & 5,342 \\
Legal : Other & 65,899 & 0.008 & 517 \\
Nb of empl.:None & 65,899 & 0.195 & 12,835 \\
Nb of empl.:Inf. to 10 & 65,899 & 0.61 & 40,188 \\
Nb of empl.:Btw. 10\&49 & 65,899 & 0.17 & 11,211 \\
Nb of empl.:Btw. 50\&249 & 65,899 & 0.023 & 1,497 \\
Nb of empl.:Sup. to 250 & 65,899 & 0.002 & 168
\end{tabular}

Table 7: Breakdown of size (empl.) for financials

The table displays information on the financials information used in the tests. The "length in months since financials" show these information remain valid for analysis. $75 \%$ are less than 16 months old. All ratios have been winsorized at the $1^{\text {st }}$ and $99^{\text {th }}$ centile because of asymptotic issues.

\begin{tabular}{l||c|ccccc} 
& Obs. & Mean & Median & sd & Q1 & Q3 \\
\hline Last financials (months) & 32,638 & 11.243 & 10.908 & 6.22 & 6.21 & 16.07 \\
\hline Fixed Assets/Equity & 32,638 & 0.987 & 0.858 & 7.98 & -0.24 & 1.92 \\
Profit. margin & 32,638 & -0.099 & -0.032 & 0.26 & -0.13 & 0.02 \\
Weight of wages & 32,638 & 1.071 & 0.993 & 1.48 & 0.83 & 1.25 \\
\hline Ln(size) & 32,638 & 12.567 & 12.466 & 1.38 & 11.66 & 13.37 \\
Ln(Fixed Assets) & 32,638 & 11.623 & 11.677 & 1.69 & 10.59 & 12.63 \\
Ln(Payables) & 32,638 & 11.184 & 11.124 & 1.67 & 10.09 & 12.24
\end{tabular}

Table 9: Breakdown of business sectors for financials 
This table provides the breakdown by business sectors of available financials in the 24 months before filing for bankruptcy. There are only two sectors with less than half their firms

\begin{tabular}{lccc} 
& Obs & $\begin{array}{c}\text { Without } \\
\text { Financials }\end{array}$ & $\begin{array}{c}\text { With } \\
\text { Financials }\end{array}$ \\
\hline Manufacturing & 8,737 & $31 \%$ & $69 \%$ \\
Construction & 19,183 & $50 \%$ & $50 \%$ \\
Wholesale \& retail & 15,479 & $48 \%$ & $52 \%$ \\
Transportation \& storage & 3,078 & $41 \%$ & $59 \%$ \\
Accommodation \& food & 10,060 & $55 \%$ & $45 \%$ \\
Serv. & 2,013 & $48 \%$ & $52 \%$ \\
Inform. \& Com. & 2,146 & $49 \%$ & $51 \%$ \\
Real estate activities & 3,705 & $52 \%$ & $48 \%$ \\
Administrative \& support & 747 & $40 \%$ & $60 \%$ \\
activ. & 503 & $34 \%$ & $66 \%$ \\
Arducation & 248 & $38 \%$ & $62 \%$ \\
Energy, Water, Waste mgmt & 65,899 & $47 \%$ & $53 \%$
\end{tabular}

Table 10: Breakdown of size (nbr. of empl.) for financials

This table shows the breakdown by size of available financials in the 24 months before filing for bankruptcy. Overall, more than half of the population displays available data but the table also shows a size bias towards larger firms.

\begin{tabular}{lccc} 
& Obs. & $\begin{array}{c}\text { Without } \\
\text { Financials }\end{array}$ & $\begin{array}{c}\text { With } \\
\text { Financials }\end{array}$ \\
\hline No empl. & 12,835 & $74 \%$ & $26 \%$ \\
Btw. 1 \& 10 empl. & 40,188 & $47 \%$ & $53 \%$ \\
Btw. 10 \& 49 & 11,211 & $23 \%$ & $77 \%$ \\
Btw. 50 \& 249 empl. & 1,497 & $17 \%$ & $83 \%$ \\
Above 250 empl. & 168 & $18 \%$ & $82 \%$ \\
\hline Total & 65,899 & $47 \%$ & $53 \%$
\end{tabular}

\subsection{Econometric analysis}

Table 11: Testing the impact of local unempl. at filing with financials

This table provides an evaluation of the impact of the economic environment on the two samples, i.e. the whole population (a) and the firms with available financials (b). For controls, we had available the business sector, the age, the motive of creation, the legal form and some sectorial ratios - the weights of labour and debts, the variation in profitability margin and the weight of bank debts in total debts. All three possible outcomes are considered : reorganization plan (1), sale as a going concern (2) and conversion into Liquidation (3).

\begin{tabular}{lllllll} 
& $(1 \mathrm{a})$ & $(2 \mathrm{a})$ & $(3 \mathrm{a})$ & $(1 \mathrm{~b})$ & $(2 \mathrm{~b})$ & $(3 \mathrm{~b})$ \\
\hline Forum Shopping & -0.063 & $0.283^{* * *}$ & $0.136^{* * *}$ & -0.101 & 0.009 & $0.162^{* *}$ \\
& $(0.062)$ & $(0.093)$ & $(0.042)$ & $(0.076)$ & $(0.115)$ & $(0.065)$
\end{tabular}

Environment : 


\begin{tabular}{|c|c|c|c|c|c|c|}
\hline & (1a) & $(2 a)$ & $(3 a)$ & $(1 b)$ & $(2 \mathrm{~b})$ & $(3 \mathrm{~b})$ \\
\hline Var in GDP & $\begin{array}{l}0.010 \\
(0.016)\end{array}$ & $\begin{array}{l}0.010 \\
(0.034)\end{array}$ & $\begin{array}{l}0.020^{*} \\
(0.012)\end{array}$ & $\begin{array}{l}-0.004 \\
(0.019)\end{array}$ & $\begin{array}{l}0.015 \\
(0.038)\end{array}$ & $\begin{array}{l}0.030 \\
(0.018)\end{array}$ \\
\hline Local unempl. rate & $\begin{array}{l}0.044^{* * *} \\
(0.016)\end{array}$ & $\begin{array}{l}0.003 \\
(0.025)\end{array}$ & $\begin{array}{l}0.014^{* *} \\
(0.006)\end{array}$ & $\begin{array}{l}0.037^{* *} \\
(0.019)\end{array}$ & $\begin{array}{l}0.022 \\
(0.030)\end{array}$ & $\begin{array}{l}0.022^{* *} \\
(0.010)\end{array}$ \\
\hline Firm creation rate & $\begin{array}{l}0.030 \\
(0.097)\end{array}$ & $\begin{array}{l}-0.133 \\
(0.206)\end{array}$ & $\begin{array}{l}-0.070 \\
(0.062)\end{array}$ & $\begin{array}{l}0.166 \\
(0.116)\end{array}$ & $\begin{array}{l}0.003 \\
(0.242)\end{array}$ & $\begin{array}{l}0.178^{*} \\
(0.101)\end{array}$ \\
\hline \multicolumn{7}{|l|}{ Court characteristics : } \\
\hline Past proceedings & $\begin{array}{l}0.000 \\
(0.000)\end{array}$ & $\begin{array}{l}0.000 \\
(0.000)\end{array}$ & $\begin{array}{l}0.000 \\
(0.000)\end{array}$ & $\begin{array}{l}0.000 \\
(0.000)\end{array}$ & $\begin{array}{l}0.000 \\
(0.000)\end{array}$ & $\begin{array}{l}0.000^{*} \\
(0.000)\end{array}$ \\
\hline Past Liquidation & $\begin{array}{l}-0.004 \\
(0.002)\end{array}$ & $\begin{array}{l}0.000 \\
(0.005)\end{array}$ & $\begin{array}{l}-0.002 \\
(0.001)\end{array}$ & $\begin{array}{l}-0.003 \\
(0.003)\end{array}$ & $\begin{array}{l}-0.004 \\
(0.005)\end{array}$ & $\begin{array}{l}0.001 \\
(0.002)\end{array}$ \\
\hline Past Sauvegarde & $\begin{array}{l}0.012 \\
(0.007)\end{array}$ & $\begin{array}{l}-0.007 \\
(0.018)\end{array}$ & $\begin{array}{l}-0.004 \\
(0.005)\end{array}$ & $\begin{array}{l}0.015^{*} \\
(0.009)\end{array}$ & $\begin{array}{l}-0.003 \\
(0.021)\end{array}$ & $\begin{array}{l}-0.001 \\
(0.008)\end{array}$ \\
\hline \multicolumn{7}{|c|}{ ) } \\
\hline Inf 10 empl. & $\begin{array}{l}0.226^{* * *} \\
(0.030)\end{array}$ & $\begin{array}{l}0.076 \\
(0.079)\end{array}$ & $\begin{array}{l}-0.484^{* *} \\
(0.014)\end{array}$ & $\begin{array}{c}* 0.151^{* * *} \\
(0.046)\end{array}$ & $\begin{array}{l}-0.131 \\
(0.118)\end{array}$ & $\begin{array}{l}-0.189^{* * *} \\
(0.031)\end{array}$ \\
\hline$[10 ; 50[\mathrm{empl}$. & $\begin{array}{l}0.045 \\
(0.036)\end{array}$ & $\begin{array}{l}1.126^{* * *} \\
(0.082)\end{array}$ & $\begin{array}{l}-0.736^{* *} \\
(0.020)\end{array}$ & $\begin{array}{l}* 0.070 \\
(0.053)\end{array}$ & $\begin{array}{l}0.443^{* * *} \\
(0.122)\end{array}$ & $\begin{array}{l}-0.194^{* * *} \\
(0.039)\end{array}$ \\
\hline$[50 ; 250[$ empl. & $\begin{array}{l}-0.026 \\
(0.068)\end{array}$ & $\begin{array}{l}1.502^{* * *} \\
(0.096)\end{array}$ & $\begin{array}{l}-0.798^{* *} \\
(0.050)\end{array}$ & $\begin{array}{c}* 0.133 \\
(0.086)\end{array}$ & $\begin{array}{l}0.376^{* * *} \\
(0.142)\end{array}$ & $\begin{array}{l}-0.140^{* *} \\
(0.068)\end{array}$ \\
\hline$>249$ empl. & $\begin{array}{l}0.265 \\
(0.176)\end{array}$ & $\begin{array}{l}1.742^{* * *} \\
(0.148)\end{array}$ & $\begin{array}{l}-1.042^{* *} \\
(0.158)\end{array}$ & $\begin{array}{c}k^{*} 0.629^{* * * *} \\
(0.200)\end{array}$ & $\begin{array}{l}0.146 \\
(0.202)\end{array}$ & $\begin{array}{l}-0.200 \\
(0.198)\end{array}$ \\
\hline \multicolumn{7}{|l|}{ Financials : } \\
\hline F.A / Equity & & & & $\begin{array}{l}0.001 \\
(0.001)\end{array}$ & $\begin{array}{l}0.000 \\
(0.003)\end{array}$ & $\begin{array}{l}0.000 \\
(0.001)\end{array}$ \\
\hline Profit margin & & & & $\begin{array}{l}0.249^{* * *} \\
(0.045)\end{array}$ & $\begin{array}{l}0.308^{* * *} \\
(0.099)\end{array}$ & $\begin{array}{l}-0.034 \\
(0.035)\end{array}$ \\
\hline Weight of wages & & & & $\begin{array}{l}-0.001 \\
(0.007)\end{array}$ & $\begin{array}{l}-0.035^{* *} \\
(0.015)\end{array}$ & $\begin{array}{l}-0.003 \\
(0.006)\end{array}$ \\
\hline $\ln ($ Size $)$ & & & & $\begin{array}{l}-0.116^{* *-} \\
(0.018)\end{array}$ & $\begin{array}{c}* 0.373^{* * *} \\
(0.041)\end{array}$ & $\begin{array}{l}0.086^{* * *} \\
(0.015)\end{array}$ \\
\hline $\ln$ (Assets) & & & & $\begin{array}{l}0.019^{*} \\
(0.011)\end{array}$ & $\begin{array}{l}-0.065^{* * *} \\
(0.022)\end{array}$ & $\begin{array}{c}*-0.151^{* * *} \\
(0.008)\end{array}$ \\
\hline $\ln$ (Payables) & & & & $\begin{array}{l}-0.011 \\
(0.012)\end{array}$ & $\begin{array}{l}0.067^{* *} \\
(0.028)\end{array}$ & $\begin{array}{l}-0.052^{* * *} \\
(0.010)\end{array}$ \\
\hline Controls & & & & Yes & & \\
\hline $\mathrm{AIC}$ & 126067 & 33222 & 391228 & 80474 & 22603 & 137189 \\
\hline Num. events & 14363 & 3192 & 34157 & 10085 & 2395 & 13639 \\
\hline Num. obs. & 65899 & 65899 & 65899 & 33945 & 33945 & 33945 \\
\hline
\end{tabular}


Table 12: Testing the impact of local unempl. at filing with financials and time-dependent variables

This table provides an evaluation of the impact of the economic environment on the two samples and considering their effect as time-dependent. We add the same controls than described in Table. All three possible outcomes are considered : reorganization plan (1), sale as a going concern (2) and conversion into Liquidation (3).

\begin{tabular}{|c|c|c|c|c|c|c|}
\hline & $(1 \mathrm{a})$ & $(2 \mathrm{a})$ & $(3 a)$ & $(1 \mathrm{~b})$ & $(2 \mathrm{~b})$ & $(3 \mathrm{~b})$ \\
\hline Forum Shopping & $\begin{array}{l}-0.063 \\
(0.062)\end{array}$ & $\begin{array}{l}0.286^{* * *} \\
(0.093)\end{array}$ & $\begin{array}{l}0.133^{* * *} \\
(0.042)\end{array}$ & $\begin{array}{l}-0.094 \\
(0.076)\end{array}$ & $\begin{array}{l}0.015 \\
(0.115)\end{array}$ & $\begin{array}{l}0.161^{* *} \\
(0.065)\end{array}$ \\
\hline \multicolumn{7}{|l|}{ Environment : } \\
\hline Var in GDP & $\begin{array}{l}-0.037^{* *} \\
(0.018)\end{array}$ & $\begin{array}{l}0.006 \\
(0.038)\end{array}$ & $\begin{array}{l}-0.050^{\text {*** }} \\
(0.013)\end{array}$ & $\begin{array}{c}*-0.038^{*} \\
(0.022)\end{array}$ & $\begin{array}{l}0.010 \\
(0.044)\end{array}$ & $\begin{array}{l}-0.107^{\text {*** }} \\
(0.021)\end{array}$ \\
\hline Local unempl. rate & $\begin{array}{l}0.039^{* * *} \\
(0.009)\end{array}$ & $\begin{array}{l}0.006 \\
(0.020)\end{array}$ & $\begin{array}{l}0.015^{\text {*** }} \\
(0.005)\end{array}$ & $\begin{array}{l}0.033^{\text {*** }} \\
(0.011)\end{array}$ & $\begin{array}{l}0.015 \\
(0.025)\end{array}$ & $\begin{array}{l}0.019^{* *} \\
(0.008)\end{array}$ \\
\hline Firm creation rate & $\begin{array}{l}0.030 \\
(0.096)\end{array}$ & $\begin{array}{l}-0.042 \\
(0.197)\end{array}$ & $\begin{array}{l}-0.213^{\text {*** }} \\
(0.060)\end{array}$ & $\begin{array}{r}*-0.009 \\
(0.116)\end{array}$ & $\begin{array}{l}-0.006 \\
(0.232)\end{array}$ & $\begin{array}{l}0.018 \\
(0.097)\end{array}$ \\
\hline \multicolumn{7}{|c|}{ Court characteristics : } \\
\hline Past proceedings & $\begin{array}{l}0.000 \\
(0.000)\end{array}$ & $\begin{array}{l}0.000 \\
(0.000)\end{array}$ & $\begin{array}{l}0.000 \\
(0.000)\end{array}$ & $\begin{array}{l}0.000 \\
(0.000)\end{array}$ & $\begin{array}{l}0.000 \\
(0.000)\end{array}$ & $\begin{array}{l}0.000^{*} \\
(0.000)\end{array}$ \\
\hline Past Liquidation & $\begin{array}{l}0.001 \\
(0.002)\end{array}$ & $\begin{array}{l}-0.003 \\
(0.005)\end{array}$ & $\begin{array}{l}-0.003^{*} \\
(0.001)\end{array}$ & $\begin{array}{l}0.001 \\
(0.003)\end{array}$ & $\begin{array}{l}-0.007 \\
(0.006)\end{array}$ & $\begin{array}{l}0.001 \\
(0.002)\end{array}$ \\
\hline Past Sauvegarde & $\begin{array}{l}-0.012 \\
(0.007)\end{array}$ & $\begin{array}{l}0.005 \\
(0.017)\end{array}$ & $\begin{array}{l}-0.009^{*} \\
(0.005)\end{array}$ & $\begin{array}{l}-0.005 \\
(0.009)\end{array}$ & $\begin{array}{l}-0.002 \\
(0.020)\end{array}$ & $\begin{array}{c}-0.004 \\
(0.008)\end{array}$ \\
\hline \multicolumn{7}{|l|}{ Firm size : } \\
\hline Inf 10 empl. & $\begin{array}{l}0.225^{* * *} \\
(0.030)\end{array}$ & $\begin{array}{l}0.074 \\
(0.079)\end{array}$ & $\begin{array}{l}-0.481^{\text {*** }} \\
(0.014)\end{array}$ & $\begin{array}{c}* 0.149^{* * *} \\
(0.046)\end{array}$ & $\begin{array}{l}-0.142 \\
(0.117)\end{array}$ & $\begin{array}{l}-0.186^{\text {*** }} \\
(0.031)\end{array}$ \\
\hline$[10 ; 50[$ empl. & $\begin{array}{l}0.042 \\
(0.036)\end{array}$ & $\begin{array}{l}1.126^{* * *} \\
(0.082)\end{array}$ & $\begin{array}{l}-0.735^{\text {*** }} \\
(0.020)\end{array}$ & $\begin{array}{l}{ }^{*} 0.066 \\
(0.053)\end{array}$ & $\begin{array}{l}0.432^{* * *} \\
(0.122)\end{array}$ & $\begin{array}{l}-0.190^{\text {*** }} \\
(0.039)\end{array}$ \\
\hline$[50 ; 250[$ empl. & $\begin{array}{c}-0.028 \\
(0.068)\end{array}$ & $\begin{array}{l}1.501^{* * *} \\
(0.096)\end{array}$ & $\begin{array}{l}-0.790^{\text {*** }} \\
(0.050)\end{array}$ & $\begin{array}{l}* 0.123 \\
(0.086)\end{array}$ & $\begin{array}{l}0.360^{* *} \\
(0.142)\end{array}$ & $\begin{array}{l}-0.127^{*} \\
(0.069)\end{array}$ \\
\hline$>249$ empl. & $\begin{array}{l}0.266 \\
(0.177)\end{array}$ & $\begin{array}{l}1.755^{* * *} \\
(0.148)\end{array}$ & $\begin{array}{l}-1.037^{\text {*** }} \\
(0.158)\end{array}$ & $\begin{array}{c}* 0.625^{* * *} \\
(0.200)\end{array}$ & $\begin{array}{l}0.130 \\
(0.202)\end{array}$ & $\begin{array}{c}-0.193 \\
(0.198)\end{array}$ \\
\hline \multicolumn{7}{|l|}{ Financials : } \\
\hline F.A / Equity & & & & $\begin{array}{l}0.001 \\
(0.001)\end{array}$ & $\begin{array}{l}0.000 \\
(0.003)\end{array}$ & $\begin{array}{l}0.000 \\
(0.001)\end{array}$ \\
\hline Profit margin & & & & $\begin{array}{l}0.249^{* * *} \\
(0.045)\end{array}$ & $\begin{array}{l}0.299^{* * *} \\
(0.099)\end{array}$ & $\begin{array}{l}-0.035 \\
(0.035)\end{array}$ \\
\hline Weight of wages & & & & $\begin{array}{l}-0.002 \\
(0.007)\end{array}$ & $\begin{array}{l}-0.036^{* *} \\
(0.015)\end{array}$ & $\begin{array}{c}-0.003 \\
(0.006)\end{array}$ \\
\hline $\ln ($ Size $)$ & & & & $\begin{array}{l}-0.117^{*} \\
(0.018)\end{array}$ & $\begin{array}{c}* 0.373^{* * *} \\
(0.041)\end{array}$ & $\begin{array}{l}0.086^{* * *} \\
(0.015)\end{array}$ \\
\hline $\ln$ (Assets) & & & & $\begin{array}{l}0.018 \\
(0.011)\end{array}$ & $\begin{array}{l}-0.064^{* * *} \\
(0.022)\end{array}$ & $\begin{array}{c}*-0.152^{* * *} \\
(0.008)\end{array}$ \\
\hline $\ln$ (Payables) & & & & $\begin{array}{l}-0.009 \\
(0.012)\end{array}$ & $\begin{array}{l}0.067^{* *} \\
(0.028)\end{array}$ & $\begin{array}{l}-0.051^{\text {*** }} \\
(0.010)\end{array}$ \\
\hline Controls & & & & Yes & & \\
\hline
\end{tabular}




\begin{tabular}{lllllll} 
& $(1 \mathrm{a})$ & $(2 \mathrm{a})$ & $(3 \mathrm{a})$ & $(1 \mathrm{~b})$ & $(2 \mathrm{~b})$ & $(3 \mathrm{~b})$ \\
\hline AIC & 126039 & 33210 & 391098 & 80195 & 22557 & 136716 \\
Num. events & 14363 & 3192 & 34155 & 10052 & 2392 & 13603 \\
Num. obs. & 183753 & 183753 & 183753 & 111802 & 111802 & 111802 \\
${ }^{* * *} p<0.01,{ }^{* *} p<0.05,{ }^{*} p<0.1$ & & & & &
\end{tabular}

Table 13: Testing the impact of environment with shared frailty

This table provides an evaluation of the impact of the economic environment on the two samples with shared frailty and a frailty model following a gamma law. This parametrization does not allow us to add the past proceedings in the explaining variables. The variance of the Random Effect is always significant at the highest level but largely differs among the alternatives. It is the highest for the continuation plan. Otherwise, we have the same controls as those described in Table. All three possible outcomes are considered : reorganization plan (1), sale as a going concern (2) and conversion into Liquidation (3).

\begin{tabular}{|c|c|c|c|c|c|c|}
\hline & (1a) & (2a) & (3a) & (1b) & $(2 \mathrm{~b})$ & $(3 \mathrm{~b})$ \\
\hline Forum Shopping & $\begin{array}{l}-0.130^{* *} \\
(0.058)\end{array}$ & $\begin{array}{l}0.192^{* *} \\
(0.089)\end{array}$ & $\begin{array}{l}0.126^{* * *} \\
(0.042)\end{array}$ & $\begin{array}{l}-0.178^{* *} \\
(0.071)\end{array}$ & $\begin{array}{l}-0.050 \\
(0.106)\end{array}$ & $\begin{array}{l}0.095^{*} \\
(0.057)\end{array}$ \\
\hline \multicolumn{7}{|l|}{ Environment } \\
\hline Var in GDP & $\begin{array}{l}-0.043^{* *} \\
(0.018)\end{array}$ & $\begin{array}{l}0.001 \\
(0.037)\end{array}$ & $\begin{array}{l}-0.054^{* *} \\
(0.012)\end{array}$ & $\begin{array}{c}*-0.049^{* *} \\
(0.022)\end{array}$ & $\begin{array}{l}-0.004 \\
(0.043)\end{array}$ & $\begin{array}{l}-0.111^{* * *} \\
(0.021)\end{array}$ \\
\hline Local unempl. rate & $\begin{array}{l}0.039^{* * *} \\
(0.009)\end{array}$ & $\begin{array}{l}-0.017 \\
(0.016)\end{array}$ & $\begin{array}{l}0.017^{* * *} \\
(0.005)\end{array}$ & $\begin{array}{l}0.030^{* * *} \\
(0.011)\end{array}$ & $\begin{array}{l}-0.016 \\
(0.019)\end{array}$ & $\begin{array}{l}0.006 \\
(0.007)\end{array}$ \\
\hline Firm creation rate & $\begin{array}{l}0.031 \\
(0.094)\end{array}$ & $\begin{array}{l}0.002 \\
(0.189)\end{array}$ & $\begin{array}{l}-0.210^{* *} \\
(0.060)\end{array}$ & $\begin{array}{r}{ }^{*}-0.069 \\
(0.114)\end{array}$ & $\begin{array}{l}-0.034 \\
(0.221)\end{array}$ & $\begin{array}{l}-0.064 \\
(0.094)\end{array}$ \\
\hline \multicolumn{7}{|l|}{ Court characteristics: } \\
\hline Past Liquidation & $\begin{array}{l}0.001 \\
(0.002)\end{array}$ & $\begin{array}{l}0.011^{* * *} \\
(0.003)\end{array}$ & $\begin{array}{l}-0.003^{*} \\
(0.001)\end{array}$ & $\begin{array}{l}0.000 \\
(0.003)\end{array}$ & $\begin{array}{l}0.007^{*} \\
(0.004)\end{array}$ & $\begin{array}{l}0.001 \\
(0.002)\end{array}$ \\
\hline Past Sauvegarde & $\begin{array}{l}-0.014^{* *} \\
(0.007)\end{array}$ & $\begin{array}{l}0.011 \\
(0.015)\end{array}$ & $\begin{array}{l}-0.009^{*} \\
(0.005)\end{array}$ & $\begin{array}{l}-0.009 \\
(0.008)\end{array}$ & $\begin{array}{l}0.004 \\
(0.017)\end{array}$ & $\begin{array}{l}-0.009 \\
(0.006)\end{array}$ \\
\hline \multicolumn{7}{|l|}{ Firm size: } \\
\hline Inf 10 empl. & $\begin{array}{l}0.242^{* * *} \\
(0.030)\end{array}$ & $\begin{array}{l}0.080 \\
(0.079)\end{array}$ & $\begin{array}{l}-0.485^{* *} \\
(0.013)\end{array}$ & $\begin{array}{c}* 0.145^{* * *} \\
(0.045)\end{array}$ & $\begin{array}{l}-0.186 \\
(0.117)\end{array}$ & $\begin{array}{l}-0.194^{* * *} \\
(0.031)\end{array}$ \\
\hline$[10 ; 50[$ empl. & $\begin{array}{l}0.058 \\
(0.035)\end{array}$ & $\begin{array}{l}1.144^{* * *} \\
(0.081)\end{array}$ & $\begin{array}{l}-0.738^{* *} \\
(0.020)\end{array}$ & $\begin{array}{l}* 0.046 \\
(0.053)\end{array}$ & $\begin{array}{l}0.394^{* * *} \\
(0.121)\end{array}$ & $\begin{array}{l}-0.209^{* * *} \\
(0.039)\end{array}$ \\
\hline$[50 ; 250[\mathrm{empl}$. & $\begin{array}{l}-0.043 \\
(0.067)\end{array}$ & $\begin{array}{l}1.525^{* * *} \\
(0.096)\end{array}$ & $\begin{array}{l}-0.796^{* *} \\
(0.050)\end{array}$ & $\begin{array}{l}{ }^{*} 0.080 \\
(0.085)\end{array}$ & $\begin{array}{l}0.339^{* *} \\
(0.141)\end{array}$ & $\begin{array}{l}-0.149^{* *} \\
(0.068)\end{array}$ \\
\hline > 249 empl. & $\begin{array}{l}0.312^{*} \\
(0.175)\end{array}$ & $\begin{array}{l}1.793^{* * *} \\
(0.146)\end{array}$ & $\begin{array}{l}-1.043^{* *} \\
(0.158)\end{array}$ & $\begin{array}{c}*^{*} 0.600^{* * * *} \\
(0.198)\end{array}$ & $\begin{array}{l}0.070 \\
(0.200)\end{array}$ & $\begin{array}{l}-0.267 \\
(0.198)\end{array}$ \\
\hline \multicolumn{7}{|l|}{ Financials : } \\
\hline F.A / Equity & & & & $\begin{array}{l}0.001 \\
(0.001)\end{array}$ & $\begin{array}{l}0.000 \\
(0.003)\end{array}$ & $\begin{array}{l}0.000 \\
(0.001)\end{array}$ \\
\hline Profit margin & & & & $\begin{array}{l}0.251^{* * *} \\
(0.044)\end{array}$ & $\begin{array}{l}0.296^{* * *} \\
(0.099)\end{array}$ & $\begin{array}{l}-0.044 \\
(0.035)\end{array}$ \\
\hline Weight of wages & & & & $\begin{array}{l}-0.001 \\
(0.007)\end{array}$ & $\begin{array}{l}-0.033^{* *} \\
(0.015)\end{array}$ & $\begin{array}{l}-0.004 \\
(0.006)\end{array}$ \\
\hline
\end{tabular}




\begin{tabular}{lllllll} 
& $(1 \mathrm{a})$ & $(2 \mathrm{a})$ & $(3 \mathrm{a})$ & $(1 \mathrm{~b})$ & $(2 \mathrm{~b})$ & $(3 \mathrm{~b})$ \\
\hline $\ln ($ Size $)$ & & & & $-0.129^{* * *} 0.368^{* * *}$ & $0.090^{* * *}$ \\
& & & & $(0.018)$ & $(0.041)$ & $(0.015)$ \\
$\ln$ (Assets) & & & & $0.028^{* * *}$ & $-0.062^{* * *}-0.150^{* * *}$ \\
& & & & $(0.011)$ & $(0.022)$ & $(0.008)$ \\
$\ln$ (Payables) & & & & -0.006 & $0.069^{* *}$ & $-0.051^{* * *}$ \\
& & & & $(0.012)$ & $(0.028)$ & $(0.010)$ \\
\hline Variance of RE & $0.676^{* * *}$ & $0.143^{* * *}$ & $0.330^{* * *}$ & $0.560^{* * *}$ & $0.134^{* * *}$ & $0.033^{* * *}$ \\
\hline Controls & & \multicolumn{5}{c}{ Yes } \\
\hline AIC & 258102 & 61440 & 703448 & 172254 & 43757 & 262652 \\
Num. events & 14363 & 3192 & 34155 & 10052 & 2392 & 13603 \\
Num. obs. & 183753 & 183753 & 183753 & 107698 & 107698 & 107698 \\
\hline
\end{tabular}

${ }^{* * *} p<0.01,{ }^{* *} p<0.05,{ }^{*} p<0.1$

Table 14: Testing the impact of local and national unemployment rate

This table provides an evaluation of the impact of local unemployment rate controlling for the effect of national unemployment rate. The tests is on the two samples with time-dependency. We add the same controls as those described in Table. All three possible outcomes are considered : reorganization plan (1), sale as a going concern (2) and conversion into Liquidation (3).

\begin{tabular}{lllllll} 
& $(1 \mathrm{a})$ & $(2 \mathrm{a})$ & $(3 \mathrm{a})$ & $(1 \mathrm{~b})$ & $(2 \mathrm{~b})$ & $(3 \mathrm{~b})$ \\
\hline Forum Shopping & -0.063 & $0.286^{* * *}$ & $0.129^{* * *}$ & -0.094 & 0.015 & $0.154^{* *}$ \\
& $(0.062)$ & $(0.093)$ & $(0.042)$ & $(0.076)$ & $(0.115)$ & $(0.065)$ \\
Environment : & & & & & & \\
Var in GDP & $-0.036^{*}$ & -0.006 & -0.020 & $-0.038^{*}$ & -0.002 & $-0.057^{* * *}$ \\
& $(0.019)$ & $(0.038)$ & $(0.013)$ & $(0.023)$ & $(0.044)$ & $(0.022)$ \\
Local unempl. rate & 0.045 & $-0.092^{*}$ & $0.271^{* * *}$ & 0.034 & -0.070 & $0.363^{* * *}$ \\
& $(0.031)$ & $(0.056)$ & $(0.019)$ & $(0.037)$ & $(0.066)$ & $(0.032)$ \\
Local - national & $0.038^{* * *}$ & 0.021 & -0.006 & $0.033^{* * *}$ & 0.030 & -0.009 \\
unempl. rate & & & & & & \\
& $(0.009)$ & $(0.022)$ & $(0.005)$ & $(0.011)$ & $(0.027)$ & $(0.009)$ \\
Firm creation rate & 0.032 & -0.080 & $-0.191^{* * *}-0.009$ & -0.044 & 0.064 \\
& $(0.096)$ & $(0.199)$ & $(0.060)$ & $(0.117)$ & $(0.234)$ & $(0.097)$ \\
Court characteristics & & & & & & \\
Past proceedings & 0.000 & 0.000 & $0.000^{*}$ & 0.000 & 0.000 & 0.000 \\
& $(0.000)$ & $(0.000)$ & $(0.000)$ & $(0.000)$ & $(0.000)$ & $(0.000)$ \\
Past Liquidation & 0.001 & -0.002 & $-0.004^{* * *} 0.001$ & -0.007 & -0.001 \\
& $(0.002)$ & $(0.005)$ & $(0.001)$ & $(0.003)$ & $(0.006)$ & $(0.002)$ \\
Past Sauvegarde & -0.012 & 0.005 & $-0.009^{*}$ & -0.005 & -0.003 & -0.005 \\
& $(0.007)$ & $(0.017)$ & $(0.005)$ & $(0.009)$ & $(0.020)$ & $(0.008)$ \\
Firm size : & & & & & & \\
Inf 10 empl. & $0.225^{* * *}$ & 0.075 & $-0.480^{* * *} 0.149^{* * *}$ & -0.141 & $-0.187^{* * *}$ \\
& $(0.030)$ & $(0.079)$ & $(0.014)$ & $(0.046)$ & $(0.118)$ & $(0.031)$ \\
[10; 50[ empl. & 0.042 & $1.126^{* * *}$ & $-0.732^{* * *} 0.066$ & $0.432^{* * *}$ & $-0.189^{* * *}$ \\
& $(0.036)$ & $(0.082)$ & $(0.020)$ & $(0.053)$ & $(0.122)$ & $(0.039)$
\end{tabular}




\begin{tabular}{|c|c|c|c|c|c|c|}
\hline & (1a) & $(2 a)$ & (3a) & (1b) & $(2 \mathrm{~b})$ & (3b) \\
\hline$[50 ; 250[$ empl. & $\begin{array}{l}-0.028 \\
(0.068)\end{array}$ & $\begin{array}{l}1.501^{* * *} \\
(0.096)\end{array}$ & $\begin{array}{l}-0.785^{* *} \\
(0.050)\end{array}$ & $\begin{array}{l}* * 0.123 \\
(0.086)\end{array}$ & $\begin{array}{l}0.360^{* *} \\
(0.142)\end{array}$ & $\begin{array}{l}-0.121^{*} \\
(0.069)\end{array}$ \\
\hline$>249$ empl. & $\begin{array}{l}0.266 \\
(0.177)\end{array}$ & $\begin{array}{l}1.757^{* * *} \\
(0.148)\end{array}$ & $\begin{array}{l}-1.039^{* *} \\
(0.158)\end{array}$ & $\begin{array}{c}* * 0.625^{* * *} \\
(0.200)\end{array}$ & $\begin{array}{l}0.135 \\
(0.202)\end{array}$ & $\begin{array}{l}-0.194 \\
(0.198)\end{array}$ \\
\hline \multicolumn{7}{|l|}{ Financials : } \\
\hline F.A / Equity & & & & $\begin{array}{l}0.001 \\
(0.001)\end{array}$ & $\begin{array}{l}0.000 \\
(0.003)\end{array}$ & $\begin{array}{l}0.000 \\
(0.001)\end{array}$ \\
\hline Profit margin & & & & $\begin{array}{l}0.249^{* * * *} \\
(0.045)\end{array}$ & $\begin{array}{l}0.300^{* * *} \\
(0.099)\end{array}$ & $\begin{array}{l}-0.036 \\
(0.035)\end{array}$ \\
\hline Weight of wages & & & & $\begin{array}{l}-0.002 \\
(0.007)\end{array}$ & $\begin{array}{l}-0.036^{* *} \\
(0.015)\end{array}$ & $\begin{array}{l}-0.003 \\
(0.006)\end{array}$ \\
\hline $\ln ($ Size $)$ & & & & $\begin{array}{l}-0.117^{* *} \\
(0.018)\end{array}$ & $\begin{array}{c}* 0.374^{* * *} \\
(0.041)\end{array}$ & $\begin{array}{l}0.085^{* * *} \\
(0.015)\end{array}$ \\
\hline $\ln$ (Assets) & & & & $\begin{array}{l}0.018 \\
(0.011)\end{array}$ & $\begin{array}{l}-0.064^{* * *} \\
(0.022)\end{array}$ & $\begin{array}{c}{ }^{*}-0.151^{* * *} \\
(0.008)\end{array}$ \\
\hline $\ln$ (Payables) & & & & $\begin{array}{l}-0.009 \\
(0.012) \\
\end{array}$ & $\begin{array}{l}0.066^{* *} \\
(0.028) \\
\end{array}$ & $\begin{array}{l}-0.052^{* * *} \\
(0.010)\end{array}$ \\
\hline Controls & & & & Yes & & \\
\hline AIC & 126041 & 33209.14: & 3390912 & 80197 & 22557 & 136589 \\
\hline Num. events & 14363 & 3192 & 34155 & 10052 & 2392 & 13603 \\
\hline Num. obs. & 183753 & 183753 & 183753 & 111802 & 111802 & 111802 \\
\hline
\end{tabular}

${ }^{* * *} p<0.01,{ }^{* *} p<0.05,{ }^{*} p<0.1$

Table 15: Testing the impact of local unemployment rate and its interaction with size

This table provides an evaluation of the differentiated impact of the economic environment depending on the firm's size, on the two samples. We add the same controls as those described in Table. All three possible outcomes are considered: reorganization plan (1), sale as a going concern (2) and conversion into Liquidation (3).

\begin{tabular}{lllllll} 
& $(1 \mathrm{a})$ & $(2 \mathrm{a})$ & $(3 \mathrm{a})$ & $(1 \mathrm{~b})$ & $(2 \mathrm{~b})$ & $(3 \mathrm{~b})$ \\
\hline Forum Shopping & $-0.159^{* * *} 0.247^{* * *}$ & $0.139^{* * *}$ & $-0.227^{* * *}-0.048$ & $0.124^{*}$ \\
& $(0.059)$ & $(0.093)$ & $(0.042)$ & $(0.073)$ & $(0.115)$ & $(0.065)$ \\
Environment : & & & \multicolumn{7}{l}{${ }^{*}$} \\
Var in GDP & 0.011 & -0.047 & $-0.130^{* * *} 0.005$ & -0.035 & $-0.155^{* * *}$ \\
& $(0.017)$ & $(0.036)$ & $(0.013)$ & $(0.021)$ & $(0.042)$ & $(0.021)$ \\
Local unempl. rate & $-0.037^{* *}$ & $-0.072^{*}$ & $-0.019^{* * *}-0.041$ & 0.012 & -0.011 \\
& $(0.017)$ & $(0.041)$ & $(0.007)$ & $(0.025)$ & $(0.056)$ & $(0.016)$ \\
Firm creation rate & $-0.702^{* * *} 0.701^{* * *}$ & $1.102^{* * *}$ & $-0.798^{* * *} 0.606^{* * *}$ & $0.945^{* * *}$ \\
& $(0.086)$ & $(0.185)$ & $(0.056)$ & $(0.104)$ & $(0.217)$ & $(0.092)$ \\
Court characteristics $:$ & & & & & & \\
Past proceedings & 0.000 & 0.000 & $-0.001^{* * *} 0.000^{* *}$ & 0.000 & 0.000 \\
& $(0.000)$ & $(0.000)$ & $(0.000)$ & $(0.000)$ & $(0.000)$ & $(0.000)$ \\
Past Liquidation & 0.002 & $-0.008^{*}$ & $-0.011^{* * *} 0.005^{*}$ & $-0.014^{* *}$ & $-0.006^{* * *}$
\end{tabular}




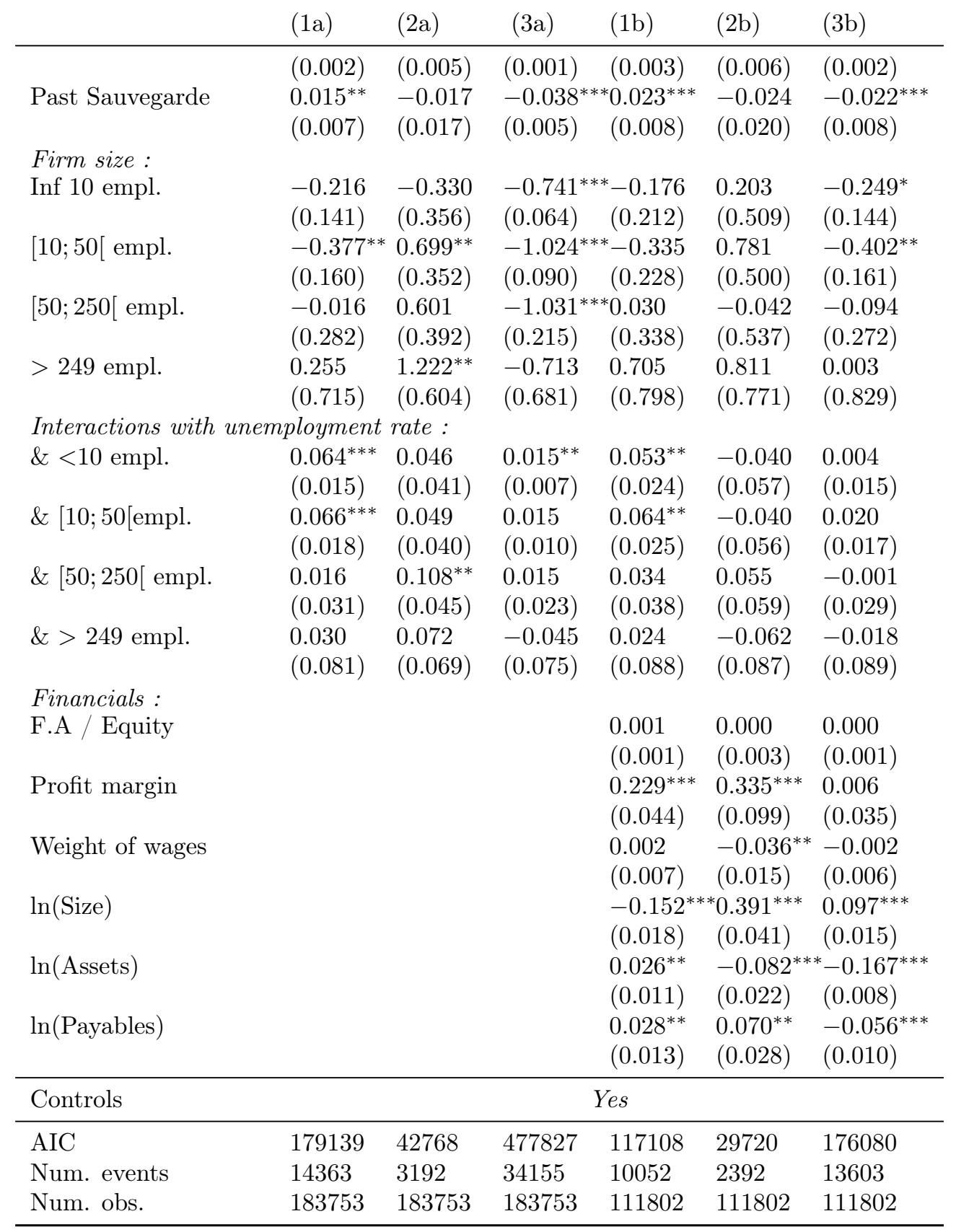

${ }^{* * *} p<0.01,{ }^{* *} p<0.05,{ }^{*} p<0.1$ 
Table 16: Testing the impact of local unemployment rate during the reorganization plan

This table provides an evaluation of the consequences of the changes in decision for the prolonged firms. We test wether the local unemployment rate still has an effect on the survival of firm. We use the value at filing (model 1) and a time-dependent model (2). The idea of the second model is to check over time between the filing and the reorganization plan the effect of the local unemployment rate, and we cluster the model with the firm under study to prevent biases in the error term. We add the same controlsas those described in Table.

\begin{tabular}{|c|c|c|c|c|}
\hline & $(1 \mathrm{a})$ & $(1 b)$ & $(2 \mathrm{a})$ & $(2 \mathrm{~b})$ \\
\hline Time before decision & $\begin{array}{l}-0.005^{* * *} \\
(0.001)\end{array}$ & $\begin{array}{l}-0.005^{* * *} \\
(0.001)\end{array}$ & $\begin{array}{l}-0.001^{* * *} \\
(0.000)\end{array}$ & $\begin{array}{l}-0.001^{* * *} \\
(0.000)\end{array}$ \\
\hline Forum Shopping & $\begin{array}{l}-0.206^{* *} \\
(0.094)\end{array}$ & $\begin{array}{l}-0.299^{* *} \\
(0.120)\end{array}$ & $\begin{array}{l}-0.171^{*} \\
(0.092)\end{array}$ & $\begin{array}{l}-0.272^{* *} \\
(0.124)\end{array}$ \\
\hline \multicolumn{5}{|l|}{ Environment } \\
\hline Var in GDP & $\begin{array}{l}-0.017 \\
(0.023)\end{array}$ & $\begin{array}{l}-0.012 \\
(0.027)\end{array}$ & $\begin{array}{l}-0.022^{* *} \\
(0.009)\end{array}$ & $\begin{array}{l}-0.016 \\
(0.011)\end{array}$ \\
\hline Local unempl. - aver. & $\begin{array}{l}0.016 \\
(0.039)\end{array}$ & $\begin{array}{l}0.001 \\
(0.047)\end{array}$ & $\begin{array}{l}-0.006 \\
(0.025)\end{array}$ & $\begin{array}{l}-0.008 \\
(0.030)\end{array}$ \\
\hline Firm creation rate & $\begin{array}{l}0.110 \\
(0.139)\end{array}$ & $\begin{array}{l}0.105 \\
(0.170)\end{array}$ & $\begin{array}{l}0.097 \\
(0.103)\end{array}$ & $\begin{array}{l}0.124 \\
(0.124)\end{array}$ \\
\hline \multicolumn{5}{|l|}{ Court characteristics } \\
\hline Past proceedings & $\begin{array}{l}0.000 \\
(0.000)\end{array}$ & $\begin{array}{l}0.000 \\
(0.000)\end{array}$ & $\begin{array}{l}0.000 \\
(0.000)\end{array}$ & $\begin{array}{l}0.000 \\
(0.000)\end{array}$ \\
\hline Past Liquidation & $\begin{array}{l}0.004 \\
(0.003)\end{array}$ & $\begin{array}{l}0.004 \\
(0.004)\end{array}$ & $\begin{array}{l}0.000 \\
(0.003)\end{array}$ & $\begin{array}{l}0.001 \\
(0.003)\end{array}$ \\
\hline Past Sauvegarde & $\begin{array}{l}-0.016 \\
(0.012)\end{array}$ & $\begin{array}{l}-0.017 \\
(0.014)\end{array}$ & $\begin{array}{l}-0.015 \\
(0.009)\end{array}$ & $\begin{array}{l}-0.016 \\
(0.011)\end{array}$ \\
\hline \multicolumn{5}{|l|}{ Firm size: } \\
\hline Inf 10 empl. & $\begin{array}{l}-0.018 \\
(0.043)\end{array}$ & $\begin{array}{l}0.016 \\
(0.066)\end{array}$ & $\begin{array}{l}-0.005 \\
(0.043)\end{array}$ & $\begin{array}{l}0.030 \\
(0.065)\end{array}$ \\
\hline$[10 ; 50[\mathrm{empl}$. & $\begin{array}{l}-0.009 \\
(0.052)\end{array}$ & $\begin{array}{l}0.095 \\
(0.078)\end{array}$ & $\begin{array}{l}0.012 \\
(0.052)\end{array}$ & $\begin{array}{l}0.134^{*} \\
(0.078)\end{array}$ \\
\hline$[50 ; 250[$ empl. & $\begin{array}{l}-0.002 \\
(0.104)\end{array}$ & $\begin{array}{l}0.198 \\
(0.132)\end{array}$ & $\begin{array}{l}0.032 \\
(0.106)\end{array}$ & $\begin{array}{l}0.252^{*} \\
(0.131)\end{array}$ \\
\hline$>249$ empl. & $\begin{array}{l}-0.068 \\
(0.276)\end{array}$ & $\begin{array}{l}0.470 \\
(0.303)\end{array}$ & $\begin{array}{l}-0.036 \\
(0.280)\end{array}$ & $\begin{array}{l}0.635^{* *} \\
(0.294)\end{array}$ \\
\hline $\begin{array}{l}\text { Financials : } \\
\text { F.A / Equity }\end{array}$ & & $\begin{array}{l}0.001 \\
(0.002)\end{array}$ & & $\begin{array}{l}0.001 \\
(0.002)\end{array}$ \\
\hline Profit margin & & $\begin{array}{l}-0.261^{* * *} \\
(0.065)\end{array}$ & & $\begin{array}{l}-0.212^{\text {*** }} \\
(0.066)\end{array}$ \\
\hline Weight of wages & & $\begin{array}{l}0.027^{* *} \\
(0.011)\end{array}$ & & $\begin{array}{l}0.023^{*} \\
(0.012)\end{array}$ \\
\hline $\ln ($ Size $)$ & & $\begin{array}{l}0.014 \\
(0.027)\end{array}$ & & $\begin{array}{l}-0.009 \\
(0.028)\end{array}$ \\
\hline $\ln$ (Assets) & & $\begin{array}{l}-0.097^{* * *} \\
(0.016)\end{array}$ & & $\begin{array}{l}-0.100^{* * *} \\
(0.016)\end{array}$ \\
\hline $\ln$ (Payables) & & 0.018 & & 0.024 \\
\hline
\end{tabular}




\begin{tabular}{lllll} 
& $(1 \mathrm{a})$ & $(1 \mathrm{~b})$ & $(2 \mathrm{a})$ & $(2 \mathrm{~b})$ \\
\hline Controls & & $(0.018)$ & & $(0.019)$ \\
\hline AIC & 58412 & 36160 & 381810 & 239457 \\
Num. events & 6592 & 4450 & 31703 & 21244 \\
Num. obs. & 14363 & 10052 & 69785 & 48549 \\
\hline${ }^{* * *} p<0.01,{ }^{* *} p<0.05,{ }^{*} p<0.1$ & & & &
\end{tabular}

${ }^{* * *} p<0.01,{ }^{* *} p<0.05,{ }^{*} p<0.1$ 